\title{
USAHA BUNUH DIRI BERDASARKAN TEORI EKOLOGI BRONFENBRENNER
}

\author{
Witrin Gamayanti \\ UIN Sunan Gunung Djati Bandung, J1. A.H. Nasution 105 \\ e-mail:w.gamayanti@gmail.com
}

\begin{abstract}
The research examine about attempted suicide an ecological Bronfenbrenner approach. The purpose of this research is to enhance our understanding about description dynamic attempted suicide. The ecological Bronfenbrenner approach allows exploration of how person whom attempted suicide is determined by multiple factors these are microsystem, mesosystem, exosystem, macrosystem, chronosystemdanontogenic system. This research is case study, qualitative method on two young women. Woman who attempted suicide is someone who intentionally injures herself but does not die. The measurement tool used deep interview and observation. The results showed that theecological influenced to decide attempted suicide.
\end{abstract}

Keywords: Attempted suicide and ecological Bronfenbrennertheory (microsystem, mesosystem, exosystem, macrosystem, chronosystem), ontogenic system.

\begin{abstract}
Abstrak
Tesis ini membahas usaha bunuh diri berdasarkan Teori Ekologi Bronfenbrenner, yaitu microsystem, mesosystem, exosystem, macrosystem, chronosystem dan ontogenic system. Hal ini diteliti karena semakin banyak usaha bunuh diri dilakukan pada berbagai usia. Tujuan penelitian adalah mendapatkan gambaran dinamika terjadinya usaha bunuh diri. Penelitian ini adalah penelitian kualitatif dengan metode studi kasus. Partisipannya wanita muda, berjumlah dua orang. Karakteristik partisipan adalah pernah melakukan usaha bunuh diri dengan niat ingin mati namun masih bisa diselamatkan dan jarak antara usaha bunuh diri dengan penelitian tidak lebih dari dua tahun. Prosedur pengambilan data dengan wawancara dan observasi. Alat bantu yang digunakan adalah perekam dan alat tulis. Kesimpulan penelitian adalah terdapat konstribusi dari microsystem, mesosystem, exosystem, macrosystem, chronosystem dan ontogenic system terhadap usaha bunuh diri yang dilakukan partisipan.
\end{abstract}

Kata kunci: usaha bunuh diri dan teori ekologi Bronfenbrenner (microsystem, mesosystem, exosystem, macrosystem, chronosystem), ontogenic system.

\section{PENDAHULUAN}

Beberapa tahun terakhir, bunuh diri menjadi fenomena yang seringkali muncul dalam pemberitaan media cetak maupun elektronik. Tindakan bunuh diri ini dilakukan oleh berbagai usia, mulai dari orang dewasa, remaja bahkan anak-anak yang masih sekolah di SD. Menurut Shneidman (1970), bunuh diri adalah fenomena yang tidak dibatasi oleh usia tertentu. Bisa terjadi pada semua usia mulai dari anak-anak sampai dengan usia tua.

Seorang anak yang masih duduk di sekolah dasar ditemukan gantung diri, namun masih bisa diselamatkan oleh kedua orang tuanya, akibatnya ia mengalami kerusakan otak. Selama beberapa detik sirkulasi oksigen ke otak terhenti, hal ini membuat beberapa bagian otaknya menjadi rusak dan mengalami retardasi mental. Tindakan ini ia lakukan dengan alasan malu ditagih SPP oleh gurunya. Kemudian, ditempat yang berbeda seorang anak ditemukan meninggal dalam kondisi gantung diri, diperkirakan masalahnya adalah tidak diperbolehkan ikut kakaknya ke Bekasi (Harian Umum Pikiran Rakyat, 2005).

Seorang remaja gantung diri karena merasa sangat kehilangan setelah ditinggal 
mati oleh ibunya. Kemudian seorang remaja lain ditemukan gantung diri karena telah menghabiskan pulsa kakaknya. Remaja putri yang masih duduk di SMP melakukan usaha bunuh diri karena ia malu diejek gendut oleh teman-temannya (Harian Umum Pikiran rakyat, 2005).

TV One, Berita Sepekan (12 Desember 2009) menayangkan usaha bunuh diri yang dilakukan oleh seorang wanita muda dengan cara melompat dari gedung lantai 4, namun berhasil diselamatkan dan pelaku sempat diwawancara. Ia menyebutkan alasannya adalah gelap mata karena merasa tertekan dengan permasalahan kerja dan merasa semua orang ingin menyingkirkannya. Kemudian, seorang pria membakar dirinya didepan sebuah mesjid diduga karena tidak tahan dengan penyakit asma kronis yang dideritanya (Harian Umum Pikiran Rakyat, 2010).

Masih banyak pemberitaan mengenai usaha bunuh diri yang tidak bisa disebutkan satu persatu. Kalau disimak dari beberapa pemberitaan, beragam alasan yang melatarbelakanginya, hal tersebut diduga sebagai trigger atau pemicu terjadinya tindakan bunuh diri. Beberapa di antaranya malu karena ditagih biaya sekolah dan uang buku oleh guru, sedih ditinggal kakak kerja, takut karena telah menghabiskan pulsa kakak, marah karena tidak diizinkan ikut ke suatu acara oleh orang tua, salah satu orang tuanya meninggal, merasa sedih yang ia sendiri tidak mengetahui penyebabnya, diputuskan pacar atau penyakit kronis yang dideritanya. Sebagian lain, tidak diketahui dengan pasti alasan tindakan bunuh diri yang dilakukan.

Cara yang dipakai untuk bunuh diri cukup beragam. Berdasarkan beberapa pemberitaan media massa, cara yang sering digunakan adalah gantung diri. Kedua, dengan meminum racun serangga, membakar diri, menusukkan senjata tajam, terjun dari ketinggian, dan menembakkan peluru ke tubuh. Namun usaha bunuh diri dengan cara menembak diri jumlahnya tidak banyak.
Jika dilihat dari kasus yang pernah terjadi, tindakan bunuh diri tidak hanya dilakukan oleh kalangan yang status sosial ekonominya rendah tetapi juga dilakukan oleh kalangan menengah keatas. Hal ini menunjukkan bahwa faktor usaha bunuh diri tidak hanya terjadi dari kalangan tertentu saja.

Tercatat sedikitnya 50 ribu orang Indonesia bunuh diri selama tiga tahun terakhir. Kemiskinan dan himpitan ekonomi menjadi penyebab tingginya jumlah orang yang mengakhiri hidup. Data tersebut dikutip dari data Organisasi Kesehatan Dunia atau World Health Organization yang dihimpun tahun 20052007 (VHRmedia.com, 2009).

Menurut Departemen Kesehatan, beberapa daerah di Indonesia, memiliki tingkat bunuh diri tinggi, antara lain Provinsi Bali mencapai 121 kasus selama tahun 2004 dan 115 kasus selama JanuariSeptember 2005, sedangkan pelaku bunuh diri dari kelompok anak-anak usia 7-15 tahun tercatat ada 8 orang, usia lanjut 8 orang. Pada tahun 2004, di Kabupaten Wonogiri, Jawa Tengah, tercatat 20 kasus bunuh diri dengan korban rata-rata berusia 51-75 tahun.Kasus bunuh diri di Jakarta sepanjang tahun 1995-2004 mencapai $5,8 \%$ per 100 ribu penduduk, kebanyakan lelaki. Dari 1.119 orang bunuh diri di Jakarta, 41\% dengan cara gantung diri, $23 \%$ meminum racun. Tingginya angka bunuh diri di Indonesia mendekati negara pemegang rekor dunia seperti Jepang mencapai lebih dari 30 ribu orang per tahun dan China yang mencapai 250 ribu orang per tahun (VHRmedia.com, 2009).

Pada acara peringatan Hari Kesehatan Jiwa Sedunia di Jakarta tahun 2007, Guru Besar Fakultas Kedokteran Universitas Trisakti, Prayitno mengatakan, beberapa faktor penyebab orang bunuh diri di antaranya, tidak punya pekerjaan (pengangguran), kemiskinan, mahalnya biaya sekolah, kesehatan dan biaya hidup, penggusuran, kesenjangan kaya miskin dan pasien gangguan mental terutama 
depresi yang tidak tertangani secara optimal (VHRmedia.com, 2009).

Bunuh diri merupakan masalah yang kompleks, karena tidak disebabkan oleh alasan tunggal. Tindakan tersebut akibat interaksi yang kompleks dari faktor biologik, genetik, psikologik, sosial budaya dan lingkungan. Sulit menjelaskan mengenai penyebab orang memutuskan bunuh diri, sedangkan dalam kondisi yang sama bahkan lebih buruk, ada orang yang justru tidak melakukan bunuh diri (Prayitno, 1982).

Beberapa penelitiantelah dilakukan untuk mengetahui penyebab orang melakukan usaha bunuh diri. Seperti yang dikemukakan oleh Canter (2004), depresi merupakan precursor yang signifikan untuk terjadinya usaha bunuh diri.

Depresi seringkali disebut sebagai faktor yang mempunyai korelasi signifikan dengan tingkah laku bunuh diri. Namun tidak semua orang yang usaha bunuh diri mengalami depresi dan sebaliknya orang depresi tidak selalu melakukan usaha bunuh diri. Depresi yang dikombinasikan dengan beberapa faktor resiko yang lainnya akan meningkatkan resiko tingkah laku bunuh diri, misalnya dengan hopeless (perasaan putus asa), penyalahgunaan obat-obatan, dan alkohol (Ayyash-Abdo, 2002).

Studi mengenai hopelessness, memperlihatkan bahwa depresi dan bunuh diri menunjukkan hasil yang tidak konsisten. Pada 281 siswa SMA dan 53 orang remaja laki-laki yang juvenile delinquent (kenakalan remaja yang sudah melanggar hukum) ditemukan bahwa hopelessness khususnya pada laki-laki tidak berhubungan secara signifikan dengan ide untuk bunuh diri ketika depresi bisa dikontrol (Cole,1989 dalam AyyashAbdo, 2002).

Hasil studi yang dilakukan oleh Lewinsohn, Rohde dan Seeley (1993) melaporkan bahwahopelessness dengan variabel psikososial lainnya tidak berkaitan dengan usaha bunuh diri jika faktor depresi bisa dikontrol. Berbeda dengan penelitian yang dilakukan oleh Mclaughlin, Miller dan Warwick (1996) hopelessness merupakan faktor yang cukup kuat dalam menentukan tingkah laku bunuh diri.

Penelitian lain menjelaskan, penyebab orang melakukan usaha bunuh diri selain dari faktor pribadi juga dipengaruhi faktor eksternal misalnya, mengalami kekerasan seksual dan kekerasan fisik, pengalaman negatif disekolah serta kurangnya keterlibatan dalam kegiatan ekstrakulikuler atau kurangnya keterlibatan dengan teman dalam aktifitas sekolah. Kurangnya dukungan dari orang tua, orang tua yang bermasalah (terlibat dalam penyalahguna-an obat terlarang, perkawinan yang penuh konflik, ada riwayat pernah melakukan bunuh diri) juga menjadi penyebab yang signifikan dalam memunculkan tingkah laku bunuh diri (Perkins \& Hartless, 2002).

Faktor lain yang signifikan untuk terjadinya bunuh diri adalah perpisahan, perceraian, atau kehilangan hubungan afeksi serta kehilangan dukungan sosial ketika berinteraksi dengan lingkungan (Canter, 2002). Rendahnya relasi antara orang tua dengan anak, tidak ada dukungan emosional ketika terjadinya permasalahan, berkorelasi dengan ide maupun tindakan bunuh diri (AyyashAbdo, 2002).

Shagle dan Barber menjelaskan bahwa self-derogation (mencela diri sendiri) berkorelasi dengan tindakan dan ide bunuh diri. Self-derogation sendiri adalah efek dari faktor-faktor sosial yaitu keluarga, sekolah, peers, dan agama (dalam Jin \& Zhang, 1998).

Budaya juga mempengaruhi perilaku bunuh diri, misalnya di Cina, dilaporkan perempuan lebih banyak melakukan tindakan bunuh diri, karena kultur di sana memandang dalam perkawinan laki-laki dianggap mempunyai peran dan derajat yang lebih tinggi. Karenanya, ketika terjadi permasalahan lebih sering menyalahkan perempuan. Sehingga perempuan lebih mudah depresi dan putus asa dan memilih bunuh diri sebagai 
penyelesaian masalahnya (Jin \& Zhang, 1998).

Di Indonesia, faktor budaya berperan besar dalam tindakan usaha bunuh diri misalnya penelitian mengenai bunuh diri yang dilakukan oleh Darmanintyas (2002) di daerah Gunung Kidul. Penelitian mengungkapkan adanya keyakinan dari masyarakat sekitar mengenai pulung gantung. Pulung gantung adalah istilah setempat untuk menamai sejenis benda angkasa yang mirip balon berekor panjang berwarna biru. Menurut kepercayaan masyarakat setempat, ketika ada pulung gantung yang melewati atau jatuh ditempat tertentu maka orang yang berada dirumah tersebut akan ada yang meninggal dengan cara gantung diri.

Penelitian lain menjelaskan, orang melakukan bunuh diri karena merasa terinspirasi oleh tayangan di televisi. Penayangan bunuh diri di beberapa media menguatkan ide bunuh diri untuk dilakukan dalam tindakan nyata, atau membuat pelaku mendapatkan ide yang "tepat" bagaimana mengakhiri hidupnya dengan cara yang cepat (Mcdowell \& Stillon, 1994).

Berdasarkan beberapa penelitian yang telah dijabarkan di atas, peneliti menyimpulkan penyebab orang melakukan bunuh diridapat dikelompokkan kedalam tiga hal. Pertama, masalah individu seperti, depresi, hopelessness, frustrasi, malu, penyalahgunaan obat terlarang. Kedua, faktor lingkungan, misalnya keluarga, sekolah, teman, tempat kerja. Ketiga, faktor budaya dan kehidupan sosial lainnya.

Seperti yang dikemukakan oleh Prayitno (2007), sulit menentukan faktorfaktor yang menyebabkan orang melakukan usaha bunuh diri. Penyebabnya tidak tunggal tetapi melibatkan beberapa faktor atau adanya kombinasi dari beberapa faktor, baik individu maupun sosial yang menjadi pemicu hebat, sehingga terjadi tindakan bunuh diri.

Untuk menggambarkan fenomena bunuh diri secara lebih sistematis dan menyeluruh, yang mencakup aspek pribadi, lingkungan, budaya dan sosial maka peneliti menggunakan teori ekologi yang dikemukakan oleh Bronfenbrenner (1979) yang menggambarkan beberapa sistem lingkungan yang mempengaruhi perkembangan individu. Sistem itu terdiri dari microsystem, mesosystem, exosystem, macrosystem dan chronosystem.

Untuk melengkapi dan mem-perluas gambaran psikologis individu yang menjadi penyebab usaha bunuh diri, peneliti menambahkan faktor ontogenic systematau person-oriented system ke dalam ke lima sistem tadi. Menurut peneliti teori ekologi Bronfenbrenner (1979) tidak cukup membahas mengenai kondisi psikologis yang secara spesifik menyebabkan seseorang melakukan usaha bunuh diri. Faktor individu menurut Bronfenbrenner (1979) adalah usia, jenis kelamin, kesehatan, kemampuan (abilities) dan temperamen. Menurut Belsky (1980), sistem ontogenik mewakili demografik dan karakteristik pelaku yang menjadi indikasi peningkatan resiko tingkah laku bunuh diri, misalnya depresi, hopelessness, penyalahgunaan obat terlarang, kekerasan seksual dan fisik.

Beberapa penelitian yang telah dikemukakan sebelumnya menggunakan metode kuantitatif namun belum melihat permasalahan ini secara gamblang dan menyeluruh dari berbagai sudut pandang, yaitu fakor pribadi, latar belakang kehidupan sosial dan budaya. Penelitian yang telah dilakukan baru melihat penyebab bunuh diri dari hubungan antara variabel psikologis yang memberikan konstribusi dan mendorong usaha bunuh diri.

Penelitian mengenai usaha bunuh diri dengan menggunakan metode kuantitatif, hanya menjelaskan aspek yang terbatas sesuai variabel penelitian yang telah ditetapkan oleh peneliti. Sementara itu, kalau dilihat kasusnya, banyak variabel yang terlibat dan membentuk suatu masalah yang mendorong pelaku melakukan usaha bunuh diri. 
Selain itu, berdasarkan hasil beberapa penelitian yang telah dijabarkan sebelumnya, terdapat ketidakkonsistenan hasil penelitian. Meskipun mengukur hubungan antar variabel yang sama, namun hasilnya berbeda ketika di ukur pada subjek yang berbeda. Hal ini menunjukkan betapa kompleksnya penyebab dari tindakan ini. Oleh sebab itu usaha bunuh diri tidak bisa dilihat dari satu sebab saja, banyak faktor yang mempengaruhi hingga seseorang memutuskan memilih cara itu untuk menyelesaikan masalahnya.

Peneliti melihat penting sekali meninjau masalah ini dari berbagai sisi. Karenanya, peneliti ingin mengetahui fenomena usaha bunuh diri secara lebih mendalam dan komprehensif berdasarkan pada teori ekologi dengan menggunakan metode kualitatif. Diharapkan diperoleh gambaran yang lebih utuh mengenai dinamika usaha bunuh diri.

\section{LANDASAN TEORI}

\section{A. Definisi dan Pengertian Bunuh Diri}

Bunuh diri / suicide berasal dari bahasa Latin, sui yang berarti of one self dan cide atau cidium yang berarti a killing (Maris, Berman \& Silverman, 2000 ).

Menurut Maris $(1991,1993)$ bunuh diri adalah membunuh diri sendiri dengan sengaja, self-harm yang terlihat jelas, selfmutilation, tingkah laku dan sikap yang self-destructive.

Rosenberg (1988, dalam Maris, Berman \& Silverman, 2000) menyatakan bahwa bunuh diri adalah kematian yang disebabkan oleh tindakannya sendiri yang disengaja untuk membunuh dirinya.

Menurut Linehan dan Shearin (1988, dalam Davison, 2006)bunuh diri secara umum adalah upaya individu untuk menyelesaikan masalah, yang dilakukan dalam kondisi stres berat dan ditandai oleh pertimbangan atas alternatif yang sangat terbatas, akhirnya penihilan diri muncul sebagai jalan terbaik.
Definisi bunuh diri yang disampaikan beberapa tokoh dari berbagai latar belakang ilmu adalah sebagai berikut:

Emile Durkheim seorang sosiolog

Suicide is applied to all cases of death resulting directly or indirectly from act of the victim himself, which he knows will produce this result. (Durkheim, 1951 hal 40) psikolog

Edwin S Shneidman seorang

Currently in the Western world suicide is a conscious act of self-induced annihilation, best understood as a multidimensional malaise in a needful individual who defines an issue for which suicide is perceived as the best solution. (Shneidman, 1985, hal 203)

\section{Karl Menninger seorang psikiater / psikoanalis \\ Suicide is (1) a murder (involving} hatred or the wish to kill), (2) a murder by the self (often involving gulit or the wish to be killed) and (3) the wish to die (involving hopelessness)(Menninger, dalam Maris, Berman \& Silverman, 2000 hal 30)

Dari definisi di atas, disimpulkan bahwa bunuh diri adalah tindakan yang dapat menyebabkan kematian, disengaja, dilakukan oleh dirinya sendiri dan pelaku menganggap tindakannya sebagai jalan yang terbaik untuk menyelesaikan masalahnya. Orang yang meninggal akibat dibunuh orang lain meskipun yang dibunuh menginginkan kematian, tidak bisa dikategorikan bunuh diri.

\section{B. Klasifikasi Bunuh Diri}

Bunuh diri (suicide) merupakan bagian kajian dari suicidology. Seperti yang dikatakan oleh Shneidman :

Suicidology can be defined as the scientific study of suicide and suicide prevention. Suicidology is the science of self destructive behaviors, thought, feelings, and so on(Shneidman, 1970 hal 4).

Dalam beberapa literatur, bunuh diri di kelompokkan kedalam beberapa 
kategori. Menurut Shneidman (1970) individu yang bunuh diri dengan tujuan ingin mati dan bunuh diri tanpa ada keinginan untuk mati, yang mengakibatkan kematian atau tidak, dikategorikan ke dalam attempted suicide. Attempted suicide dibagi kedalam dua kategori, yaitu :

1. Committed suicide, yaitu orang yang melakukan usaha bunuh diri dengan tujuan ingin mati, baik yang bisa diselamatkan atau tidak.

2. Non suicidal, yaitu orang yang melakukan usaha bunuh diri namun tidak ada keinginan untuk mati (Shneidman, 1970).

Menurut Maris, Berman dan Silverman (2000) bunuh diri diklasifikasikan ke dalam empat golongan, yaitu :

1. Completed suicide

Tindakan membunuh dirinya sendiri yang dilakukan oleh diri sendiri dengan sengaja yang mengakibatkan kematian.

2. Non fatalsuicideattempts

Seseorang yang melakukan tindakan melukai atau merusak diri sendiri yang tidak mengakibatkan kematian. Ter-masuk kedalam kategori ini adalah pertama, orang yang melakukan usaha bunuh diri dengan niat untuk mati namun bisa diselamatkan. Kedua, orang yang ambivalent, satu sisi ia melakukan usaha bunuh diri namun ti-dak sepenuhnya menginginkan ke-matian. Istilah lain yang sering digunakan adalah attempted suicide

3. Suicidal ideation

Seseorang yang mempunyai pikiran tentang bunuh diri namun tidak ia wujudkan dalam bentuk tingkah laku. Bunuh diri dan percobaan bunuh diri, diawali dengan ide atau pikiran bunuh diri.

4. Indirect self-destructive behaviors

Tingkah laku yang secara tidak lang-sung melukai diri sendiri. Tidak semua tindakan indirect selfdestructive behaviors terlihat jelas, eksplisit atau dengan sengaja. Beberapa melakukan-nya secara unconscious, dalam jangka waktu yang lama dan kronis.Termasuk kedalam kategori ini adalah perokok berat, alkoholik, olahraga dengan resiko tinggi, judi yang kompulsif, gangguan makan, stress seeking, self-mutilation, pekerjaan yang berbahaya, penyalahgunaan obat terlarang, dan chronic overwork (Maris, Berman \& Silverman, 2000).

Sesuai dengan klasifikasi yang dikemukakan oleh Maris, Berman dan Silverman (2000), responden dalam penelitian ini adalah yang tergolong dalam non fatalsuicideattempts atau attempted suicide yaitu seseorang yang melakukan usaha bunuh diri disertai keinginan untuk mati namun berhasil diselamatkan.

\section{Beberapa Mitos mengenai Bunuh Diri yang Diyakini Secara Umum}

Menurut Shneidman (1976) beberapa mitos mengenai bunuh diri yang diyakini oleh kebanyakan orang, di antaranya adalah:

1. Orang yang mengatakan bunuh diri tidak akan melakukan tindakan tersebut.

Sebanyak tiga perempat dari pelaku bunuh diri telah mengkomunikasikan niat mereka sebelumnya, mungkin sebagai upaya untuk mendapatkan pertolongan atau untuk menggertak

2. Bunuh diri dilakukan tanpa melalui peringatan

Pelaku biasanya memberikan tanda misalnya dengan mengatakan bahwa dunia akan lebih baik tanpa ada dirinya, memberikan hadiah yang istimewa atau memberikan barang yang berharga bagi pelaku.

3. Hanya dari kelas tertentu yang melakukan bunuh diri

Bunuh diri bukan kutukan bagi orang miskin atau penyakit bagi orang kaya, bunuh diri bisa terjadi pada berbagai level sosioekonomi 
4. Menjadi anggota keagamaan tertentu adalah prediktor yang baik bahwa seseorang tidak akan berpikir untuk bunuh diri

Tidak menjamin seseorang menjadi pengikut agama tertentu atau larangan agama untuk melakukan bunuh diri serta merta menghentikan niat mereka untuk bunuh diri

5. Motif bunuh diri dapat dengan mudah diketahui

Kita tidak sepenuhnya memahami mengapa orang bunuh diri. Contohnya, sebelum orang melakukan bunuh diri ia mengalami krisis keuangan yang parah, hal ini tidak berarti bahwa kondisi tersebut cukup untuk menjelaskan tindakan bunuh diri yang dilakukannya.

6. Semua yang melakukan bunuh diri dalam kondisi depresi

Seringkali tanda-tanda mengenai tin-dakan bunuh diri diabaikan karena pelaku tidak tampak sedang putus asa. Banyak orang yang melakukan bunuh diri tidak dalam kondisi depresi, beberapa terlihat tenang dan dan tidak mengalami masalah dengan dirinya

7. Seseorang yang mengalami penyakit yang mematikan tidak akan bunuh diri

Kesadaran akan kematian yang dekat dikarenakan penyakitnya tidak meng-hentikan seseorang untuk melakukan bunuh diri. Mungkin keinginan untuk mengakhiri penderitaan atau pen-deritaan orang yang dicintai men-dorong seseorang untuk menentukan kematiannya sendiri

8. Tindakan bunuh diri merupakan tindakan psikotik

Meskipun sebagian besar orang yang melakukan bunuh diri adalah orang yang tidak bahagia namun sebagian besar masih memiliki kontak dengan realitas

9. Bunuh diri dipengaruhi oleh kosmik seperti bintik matahari atau fase-fase bulan

Belum ada bukti yang bisa meyakinkan hal ini
10. Membaiknya kondisi emosional berarti mengurangi resiko bunuh diri

Seringkali orang depresi yang me-lakukan bunuh diri setelah energi mereka meningkat dan semangat mereka terangkat.

11. Bunuh diri merupakan kesepian

Meskipun ada pertentangan apakah akan melakukan bunuh diri atau tidak, keterlibatan mendalam dengan orang yang dekat seperti anak, suami, istri, kekasih bisa menjadi penyebab utama.

12. Orang-orang yang berniat bunuh diri memang ingin mati

Sebagian besar orang yang ingin melakukan bunuh diri tidak yakin kalau mereka ingin benar-benar mati. Sementara yang lain berada dalam kondisi depresi dan alkoholik, yang bila sembuh akan mengurangi keinginan mereka untuk bunuh diri. Bagi banyak orang, krisis akan berlalu dan mereka bersyukur telah dicegah untuk melakukan usaha bunuh diri.

13. Berpikir untuk bunuh diri merupakan hal yang jarang terjadi

Perkiraan prevalensi pada populasi non klinis, ditemukan sebanyak $40 \%$ - $80 \%$ pernah terpikir untuk melakukan bunuh diri sekurangkurangnya sekali dalam hidup mereka

14. Menanyakan kepada seseorang, terutama orang yang depresi, tentang bunuh diri akan memojokkannya dan menyebabkan tindakan bunuh diri yang sebenarnya tidak akan terjadi kalau tidak ditanyakan.

Salah satu yang dipelajari ahli klinis adalah menggali mengenai bunuh diri. Dari sini bisa memberikan kesempatan kepada pasien untuk mengungkapkan rahasia yang diyakininya memalukan atau mengerikan, yang bila tidak diungkapkan akan memicu usaha untuk mengisolasi diri dan depresi lebih parah.

15. Orang-orang yang mencoba bunuh diri dengan tingkat kefatalan rendah tidak 
sungguh-sungguh ingin membunuh diri sendiri.

Beberapa tidak mengetahui mengenai anatomi dan dosis pil.Memungkinkan orang ingin bunuh diri namun usaha yang dilakukan nya tidak cukup fatal dalam menghilangkan nyawanya sendiri.

\section{Teori Ekologi}

Teori ini dikemukakan oleh Urie Bronfenbrenner (1917-2005). Ia adalah seorang psikolog dari Amerika. Teori ini menggambarkan tentang proses interaksi beberapa sistem lingkungan yang mempengaruhi perkembangan manusia, yaitu microsystem, mesosystem, exosystem, macrosystem dan crhonosystem. Melalui teori ini, bisa dipahami proses dan konteks perkembangan manusia dengan menekankan pada faktor lingkungan.

Pada awalnya Bronfenbrenner, menyebut teorinya dengan istilah teori ekologi (Bronfenbrenner, 1979). Kemudian, Bronfenbrenner (Bronfenbrenner \& Maris, 1998) menambahkan pengaruh biologis pada teorinya. Namun, sepanjang pengamatan peneliti, beberapa buku menggunakan istilah yang berbeda, ada yang menyebutnya dengan teori bioekologi (Santrock, 2009), ada yang menggunakan istilah teori ekologi (Papalia, 2009; Van de Vijver, Hemert \& Poortinga, 2008; Mash, 2010). Dalam beberapa jurnal, istilah yang digunakan adalah teori ekologi. (AyyashAbdo, 2002; Canter, 2002). Hal ini disebabkan, menurut Ceci, pengaruh lingkungan masih mendominasi penjelasannya mengenai teori ini dan terlalu sedikit perhatian mengenai masalah biologis (Ceci dalam Papalia, 2008). Dalam penelitian ini, peneliti fokus pada aspek individu dan lingkungan dalam menentukan penyebab orang melakukan usaha bunuh diri. Berdasarkan hal itu , maka peneliti akan menggunakan istilah teori ekologi seperti yang diungkapkan Bronfrenbrenner dalam bukunya pada tahun 1979.
Definisi ekologi menurut
Bronfenbrenner adalah :
The ecology of human development involves the scientific study of the progressive, mutual accommodation between an active, growing human being and the changing properties of the immediate settings in which the developing person lives, as this process is affected by relations between these settings, and by the larger contexts in which the settings are embedded.

( Bronfenbrenner, 1979, hal 21)

Ada tiga hal penting yang harus diperhatikan dari definisi di atas, yaitu :

1. Perkembangan seseorang tidak hanya dilihat sebagai tabula rasa dan lingkungan yang mempengaruhi, tetapi tumbuh dinamis, bergerak progresif dan membentuk kembali lingkungan tempat di mana seseorang tinggal.

2. Menuntut adanya proses timbal balik, saling mempengaruhi dan interaksi secara langsung antara individu dengan lingkungan.

3. Lingkungan sebagai tempat untuk proses perkembangan tidak dibatasi hanya oleh satu setting saja tapi merupakan kesatuan yang saling berkaitan antara beberapa setting

Setiap makhluk atau organisme biologis berkembang dalam konteks sistem ekologi yang bisa mendukung atau melemahkan pertumbuhan. Orang perlu mengetahui mengenai ekologi laut atau hutan jika ingin memahami tentang perkembangan pohon dan ikan. Begitu juga dengan manusia, perlu memahami perkembangan ekologi lingkungan manusia untuk memahami perkembangan manusia (Papalia, 2008).

Menurut Bronfrenbrenner, perkembangan terjadi semakin kompleks, aktif, melibatkan interaksi timbal balik antara perkembangan individu dengan lingkungan sehari-hari. Proses ini dipengaruhi berbagai konteks yang bahkan mungkin tidak disadari oleh individu yang bersangkutan. Untuk memahami proses ini, harus dipelajari berbagai konteks di 
mana proses itu terjadi. Misalnya, rumah, kelas, tempat kerja, tetangga dan institusi sosial, seperti sistem pendidikan, lebih luasnya adalah budaya yang mempengaruhi keluarga, sekolah, dan apapun yang ada disekitar kehidupan individu. Bronfenbrenner menempatkan individu berada ditengah-tengah rangkaian ke lima sistem. Individu dilihat dari usia, jenis kelamin, kesehatan, kemampuan (abilities) dan temperamen (Bron-fenbrenner, 1979).

Sesuai dengan konteks penelitian, teori ini akan akan dilihat sebagai sistem lingkungan yang mempengaruhi tindakan usaha bunuh diri.

\section{Microsystem}

Sistem pertama yang paling dekat dan berpengaruh langsung terhadap kehidupan seseorang adalah microsystem.

Definisi microsystem menurut Bronfenbrenner adalah :

A microsystem is a pattern of activities, roles and interpersonal relations experienced by the developing person in a given setting with particular physical \& material characteristic Bronfenbrenner, 1979 hal 22).

Setting yang dimaksud dari definisi tadi adalah tempat di mana individu bisa berinteraksi secara langsung misalnya, rumah, sekolah, day care center, tempat bermain, tempat kerja, tetangga, peers dan lain-lain. Individu bukan penerima pasif dalam interaksi tersebut, tetapi berperan aktif dalam membangun setting. Tidak hanya individu yang dipengaruhi setting tetapi bagaimana individu juga mempengaruhi setting. Activities, roles dan interpersonal relations merupakan elemen dari microsystem. Di microsystem termasuk hubungan personal dan face to face relationship. Istilah role, adalah satu set tingkahlaku yang diharapkan, yang dikaitkan dengan posisi dalam masyarakat seperti peran ibu, anak, guru, teman dll (Bronfenbrenner, 1979).

Hal penting dari definisi ekologi adalah experienced. Digunakan untuk menunjukkan tidak hanya bagaimana seseorang berinteraksi dengan berbagai setting tetapi bagaimana hal tersebut dirasakan oleh seseorang. Faktor eksternal / lingkungan berpengaruh besar terhadap tingkah laku manusia. Aspek lingkungan lebih kuat membentuk pertumbuhan psikologis seseorang dan individu memaknai setiap peristiwa atau pengalaman ketika berinteraksi dengan lingkungan secara terus menerus (Bronfenbrenner, 1979)

Sesuai dengan tema penelitian ini, menurut Ayyash-Abdo (2002) dalam microsystem yang berpengaruh langsung pada seseorang dalam menentukan usaha bunuh diri adalah latar belakang keluarga, keluarga yang bermasalah, peer dan sekolah.

\section{Riwayat Keluarga}

Individu yang tinggal dengan keluarga yang mempunyai anggota pernah melakukan usaha bunuh diri atau bunuh diri akan menjadi orang yang berisiko tinggi melakukan usaha bunuh diri, jika dibandingkan dengan orang yang mempunyai keluarga yang tidak mempunyai sejarah bunuh diri. Alasan berbagai keluarga yang melakukan bunuh diri, menurut Schulsinger (1980), belum ditemukan secara jelas, namun ada dugaan karena faktor genetik. Selain itu, adanya riwayat orang tua yang bermasalah, hubungan yang miskin antara orangtua dan anak, riwayat keluarga yang pernah melakukan bunuh diri menempatkan seseorang menjadi punya resiko tinggi dalam melakukan bunuh diri (Brent, 1996). Penelitian yang dilakukan Brent (1996) menemukan bahwa permasalahan psikiatrik, seperti depresi, penggunaan zat terlarang, dan gangguan anti sosial pada orang tua yang melakukan usaha bunuh dirilebih tinggi jika dibandingkan dengan komunitas keluarga yang tidak punya riwayat pernah melakukan usaha bunuh diri. Efek langsung dari keluarga yang patologis adalah meningkatkan kemungkinan tindakan bunuh diri yang dilakukan oleh anak atau anggota keluarga yang lainnya. 


\section{Keluarga yang Bermasalah}

Keluarga yang bermasalah akan mempengaruhi kepribadian anak. Perkembangan kepribadiannya menjadi bermasalah dan ketika ia menginjak remaja berpengaruh terhadap kemampuan dalam menyelesaikan permasalahan yang dihadapi mereka. Definisi keluarga bermasalah berbeda diantara beberapa studi. Indikator keluarga yang bermasalah diantaranya masalah pola komunikasi anak - orangtua, hubungan orang tua - anak, atau level dari kohesi dan konflik keluarga. Paling banyak mempengaruhi usaha bunuh diri adalah faktor komunikasi dan hubungan orang tua - anak (Adam \& Brent, 1994).

Suatu studi yang dilakukan oleh Brent, Paper, Moritz dan Bauhger, (1993), menemukan bahwa terjadinya bunuh diri diawali dengan adanya konflik antara remaja-orang tua yang terjadi setahun sebelum kejadian bunuh diri. Hasil penelitian menyebutkan bahwa perempuan yang memiliki kecenderungan untuk bunuh diri mempunyai latar belakang mendapatkan kekerasan dalam keluarga pada usia 10-14 tahun, dibandingkan dengan yang tidak mempunyai kecenderungan bunuh diri. Selain itu, kurangnya kedekatan diantara anak dengan orang tua, nonsupportive, hubungan antara anak orang tua dan miskinnya komunikasi diantara mereka, emotional responsive yang rendah dari ibu juga bisa menjadi faktor yang menyebabkan seseorang melakukan bunuh diri atau usaha bunuh diri. (dalam Ayyash-Abdo, 2002)

Menurut Brent dan Perper(1993), konflik dengan orang tua dan pasangan (romantic partners) bisa menyebabkan seseorang melakukan usaha bunuh diri. (Spirito \& Overholser, 2003)

Ciri-ciri keluarga sehat menurut Bern (1997) adalah :

1. Menunjukkan cinta dan penerimaan

2. Komunikatif

3. Kohesif

4. Mengkomunikasikan nilai dan standar yang berlaku
5. Kemampuan untuk mengatasi masalah secara efektif

Ciri-ciri keluarga yang tidak sehat menurut Satir ( 1988) adalah :

1. Penghargaan yang rendah terhadap diri sendiri

2. Pola komunikasi yang tidak langsung, tidak jelas, dan tidak cukup jujur

3. Peraturan yang kaku, tidak manusiawi, tidak dapat di negosiasi dan berlangsung selamanya

4. Hubungan keluarga tersebut dengan lingkungan disekitarnya penuh dengan ketakutan, pasif, dan sikap saling menyalahkan.

\section{Peer}

Remaja merupakan periode yang ditandai dengan kebutuhan yang penting untuk mempunyai sahabat, pemenuhan kebutuhan emosional (emotional fulfillment), dan kemandirian emosional (emotional independence). Selama tahap perkembangan remaja, mereka mencari dukungan emosional kepada peers-nya yang sebelumnya dukungan tersebut diperoleh dari orangtua. Mereka mulai berbagi rahasia, rencana, perasaan dan saling menolong satu sama lain untuk memecahkan permasalahan pribadi dan konflik interpersonal. Loneliness merupakan permasalahan yang besar selama fase remaja. Sejumlah penelitian melaporkan bahwa permasalahan dengan fungsi peer bisa mengakibatkan depresi. Gangguan tingkah laku (conduct disorder), penggunaan zat terlarang juga merupakan faktor atau precursors untuk terjadinya tingkah laku bunuh diri. Studi lain melaporkan bahwa, rendahnya level dukungan sosial dari peer-nya berkaitan dengan kecenderungan untuk bunuh diri (ideation suicide) dan tingkah laku bunuh diri (Aseltin, Gore \& Colten, 1998).

Remaja yang melakukan usaha bunuh diri dilaporkan terisolasi dari peer group nya, putus hubungan dengan pacar, dan kurangnya dukungan dari teman dekat / sahabat. Fungsi peer secara langsung atau tidak terbukti berkaitan dengan masalah 
bunuh diri, permasalahan dengan peer tetap menjadi faktor resiko penting yang layak untuk dipertimbangkan terutama untuk mencegah terjadinya usaha bunuh diri pada dewasa awal (Aseltin, Gore \& Colten, 1998).

Usaha bunuh diri selain dikaitkan dengan loss juga dengan dengan konflik interpersonal. Lewinsohn, Rohde, and Seeley (1994), mengatakan bahwa kejadian dalam kehidupan seseorang yang dikaitkan dengan kemungkinan bagi seseorang untuk melakukan usaha bunuh diri adalah berkaitan dengan hubungan interpersonal misalnya, putus dengan pacar, berkelahi secara fisik dan verbal. Hawton, Fagg dan Simkins (1996) konflik dengan orang tua, dengan teman, permasalahan di sekolah dan isolasi sosial (dalam Hawton, Fagg, \& Simkins, 1996).

\section{Sekolah}

Rendahnya performance sekolah bisa mengakibatkan tindakan bunuh diri. Borowsky (2001), mengidentifikasi mengenai pengaruh sekolah terhadap usaha bunuh diri pada berbagai etnis dan ras. Hasilnya dilaporkan bahwa prestasi akademik, penerimaan, connectedness dengan sekolah dapat melindungi seseorang dari usaha bunuh diri, ada indikasi bahwa rasa memiliki dan keamanan disekolah akan mengurangi resiko usaha bunuh diri(Deman \& Leduc, 1993). Namun pada beberapa kejadian ternyata hal tersebut tidak terbukti, tidak ada kaitannya antara motif berprestasi disekolah dan permasalahan dengan sekolah dengan tingkah laku bunuh diri. (Orbach, 1988).

Beberapa pelajar terlihat termotivasi untuk bunuh diri ketika menghadapi berbagai tekanan permasalahan atau kombinasi dari berbagai persoalan misalnya tekanan tuntutan akademik, masalah interaksi sosial, dan pemilihan karir. Interaksi beberapa permasalahan membuat mereka sulit menyesuaikan diri dengan berbagai permasalahan (Carson, 1992).

\section{Mesosystem}

Definisi Mesosystemmenurut Bronfenbrenner adalah :

Mesosystem comprises the interrelations among two or more settings in which the developing person actively participates (such as for a child, the relations among home, school, and neighborhood, peer group; for an adult, among family, work and social life)(Bronfenbrenner, 1979 hal 25)

Mesosystem merupakan interelasi atau saling hubungan antara dua atau lebih microsystem. Misalnya antara rumah dengan sekolah, rumah dengan tetangga, atau antar keluarga dengan peer group. Dengan memahami ini, bisa ditarik suatu pemahaman yang jelas mengenai bagaimana individu yang sama, berinteraksi dalam berbagai situasi yang berbeda. Misalnya seorang ibu bisa jadi guru yang baik bagi siswanya di sekolah, tetapi tidak bisa jadi ibu yang baik untuk anakanaknya di rumah. Contoh lain, seorang anak bisa menyelesaikan tugas sekolah dengan baik dan memuaskan jika dikerjakan di rumah tetapi tidak bisa menuntaskannya ketika dikerjakan di kelas. Kegagalan disekolah bisa meningkatkan resiko untuk tingkah laku bunuh diri jika comorbid dengan kondisi rumah. Anak yang tidak mampu untuk mengembangkan kedekatan emosional yang sehat di rumah dan gagal disekolah mengakibatkan berkurangnya self worth dan hal ini bisa memicu terjadinya usaha bunuh diri (Orbach, 1988).

\section{Exosystem}

Definisi exosystem menurut Bronfenbrenner adalah :

An Exosystem refers to one or more settings that do not involve the developing persons as an active participant, but in which events occur that affect, or are affected by, what happens in the setting containing the developing people.

( Bronfenbrenner, 1979 hal 25)

Dasar untuk memahami pendekatan ekologi adalah memahami individu dan 
keluarganya di dalam unit sosial yang lebih luas. Sama halnya dengan mesosystem, exosystem merupakan hubungan antara dua atau lebih setting. Namun dalam exosystem, seseorang tidak memainkan peran atau terlibat secara langsung namun berpengaruh terhadap mereka.

Misalnya, kondisi anak dan suami di rumah sangat dipengaruhi kondisi ibu ketika ditempat kerja. Contoh lain, misalnya faktor media massa, beberapa kasus bunuh diri meningkat disebabkan oleh ditayangkannya peristiwa bunuh diri yang dilakukan oleh orang-orang yang mempunyai pengaruh besar terhadap masyarakat.

Menurut Ayyash-Abdo (2002) dalam exosystem yang berpengaruh pada seseorang dalam menentukan usaha bunuh diri adalah media.

\section{Media}

Beberapa penelitian mengindikasikan bahwa media berkaitan dengan tingkah laku bunuh diri. Koran, televisi, dan cerita fiksi, signifikan berkaitan secara statistik dalam meningkatkan jumlah tingkah laku bunuh diri. Peningkatan nya menjadi semakin jelas ketika kejadian mengenai bunuh diri semakin dipublikasikan secara luas. Misalnya usaha bunuh diri yang dilakukan oleh artis, ternyata berpengaruh secara signifikan pada tingkah laku bunuh diri, mungkin hal tersebut menjadi inspirasi bagi mereka dalam menyelesaiakan masalah dan memilih melakukan hal yang sama (Berman, 1988; Stack, 1987:Wasserman, 1984; Mcdowell \& Stillon, 1994).

Berbagai laporan media massa tentang bunuh diri dapat menyebabkan meningkatnya angka bunuh diri. Penelitian Philips (1974, 1977, 1985 dalam Davison, 2006 ) menunjukan beberapa hubungan sebagai berikut :

1. Bunuh diri meningkat hingga $12 \%$, setelah Marlyn Monroe meninggal

2. Publikasi kematian akibat bunuh diri yang dilakukan oleh orang yang tidak dikenal, juga mengakibatkan angka bunuh diri meningkat. Hal ini menunjukan bahwa yang penting itu adalah publisitasnya bukan siapa orang yang melakukannya.

3. Publikasi bunuh diri diikuti dengan meningkatnya jumlah kecelakaan mobil yang menyebabkan pengemudi dan penumpang tewas

4. Berbagai laporan media masa mengenai kematian wajar orang-orang terkenal tidak di ikuti peningkatan angka bunuh diri, menunjukan bahwa bukan rasa dukacita semata yang merupakan faktor berpengaruh.

\section{Macrosystem}

Macrosystem refers to consistencies, in the form and content of lower-order systems (micro-, meso-, and exo-) that exist, or could exist, at the level of the subculture or ideology underlying such consistencies (Bronfenbrenner, 1979 hal 26).

Macrosystem mencakup semua pola budaya di mana individu hidup. Budaya terdiri dari pola tingkah laku, beliefs, nilainilai yang dominan, kebiasaan, gaya hidup, ekonomi dan sistem sosial, atau semua produk dari kelompok dan orang-orang sejak masa lalu dari generasi ke generasi yang banyak mempengaruhi kehidupan seseorang saat ini. Sebaliknya, budaya dibentuk oleh individu yang terus menerus berinteraksi dengan lingkungan. Dengan melakukan eksplorasi terhadap budaya, peran macrosystem dalam tingkah laku bunuh diri dapat dianalisis.

\section{Faktor Budaya dalam Bunuh Diri}

Menurut Markus, Kitayama dan Heiman (1996), adat budaya, beliefs, dan values memberikan pengaruh langsung pada tingkah laku bunuh diri. Itu semua bisa menjadi "guide" bagi seseorang dalam menyelesaikan kesulitan atau situasi yang penuh dengan tekanan. Usaha bunuh diri dan ideation suicide merupakan refleksi dari berbagai level dukungan 
sosial, rasa memiliki, dan dukungan masyarakat (dalam Ayyash-Abdo, 2002).

Beberapa negara seperti Jepang, memandang bunuh diri (hara-kiri atau kamikaze pada saat perang dunia ke II) sebagai tindakan terhormat. Kamikaze menurut Durkheim termasuk kedalam bunuh diri altruistik (Maris, Berman \& Silverman, 2000).

Di Denmark, ada anggapan bunuh diri bukan sesuatu hal yang tabu, mereka menganggap kematian sebagai jalan untuk "reuni" dengan orang-orang yang dicintainya. Di Swedia, laki-laki sangat terpreokupasi pada performance dan kesuksesan, kegagalan dalam mencapai ambisi membuat seseorang berpotensi untuk melakukan usaha bunuh diri. Di India, seorang istri yang ditinggal mati oleh suaminya, berkeyakinan dengan menenggelamkan diri di sungai suci gangga tempat abu suami di tabur akan masuk surga. Tindakan ini akan didoakan oleh para pendeta (Maris, Berman \& Silverman, 2000).

Triandis, Kashima, Shimada dan Villareal (1986) merumuskan suatu konsep bahwa masyarakat berada pada suatu spektrum,yaitu berada pada range antara kelompok, berorientasi individualistis, kemudian menuju collectivism. Dalam budaya collective, interdependensi, interconnectedness dan integritas keluarga merupakan faktor yang mendapat perhatian. Kemudian self dipandang sebagai bagian dari kelompok. Dalam kultur individualistis, self-reliance, kompetisi, emosional detachment, dari ingroup merupakan karakteristik yang penting (dalam Ayash-Abdo, 2002).

Penelitian dari Eshun(2000) membuktikan bahwa pada masyarakat yang berasal dari budaya collectivism, tingkah laku bunuh diri lebih rendah jika dibandingkan dengan budaya individualistis seperti di Amerika. Perbedaan sikap terhadap bunuh diri juga mempengaruhi tingkah laku bunuh diri, misalnya di Afrika sikap terhadap bunuh diri negatif, bunuh diri suatu tingkah laku yang tidak bisa diterima oleh masayarakat dan orang yang melakukan bunuh diri kehilangan rasa hormat dari masyarakat.

Di Indonesia dengan keberagaman agama dan budaya, umumnya mengajarkan bahwa bunuh diri adalah sesuatu hal yang dilarang dan berkonotasi negatif. Namun demikian, berdasarkan data yang telah dikemukakan di bab I, semakin lama angka bunuh diri di Indonesia semakin banyak. Termasuk fenomena bunuh diri yang berdasarkan pada keyakinan beragama seperti yang terjadi beberapa waktu lalu, yaitu bom bunuh diri.

Di Gunung Kidul, bunuh diri dianggap menjadi suatu hal yang sangat biasa dengan adanya mitos pulung gantung, membuat masyarakat sekitar lebih permisif dalam melakukan tindakan tersebut. Pulung gantung adalah benda angkasa mirip dengan meteor yang berwarna biru. Apabila benda itu jatuh ditempat tertentu atau melewati rumah seseorang maka diyakini akan ada orang yang meninggal dengan cara gantung diri atau bunuh diri (Darmaningtyas, 2002).

\section{Chronosystem}

Menurut Bronfenbrenner dan Morris (1998), chronosystem adalah pola kejadian di lingkungan atau transisi sepanjang kehidupan seseorang, pengaruh dari kondisi sosiohistorical dan pengalaman hidup. Chronosystemberasal dari kata chronology. Sepanjang kehidup-an seseorang ia akan mengalami perubahan, mulai dari lahir sampai seseorang berada pad fase tua. Perubahan yang terjadi mencakup semua aspek psikologis seperti, kognitif afektif dan psikomotor. Lingkungan yang dihadapi oleh setiap inidividu dalam setiap fase kehidupan juga mengalami perubahan yang mempengaruhi individu dalam berperilaku. Sebaliknya, perilaku individu akan mempengaruhi lingkungan pada setiap fase kehidupannya.

Contohnya adalah perceraian merupakan suatu transisi. Penelitian Hetherington (1993 dalam Santrock, 2009), membuktikan bahwa, efek negatif 
perceraian pada anak, puncaknya terjadi setahun setelah terjadinya perceraian. Dua tahun setelah perceraian, interaksi keluarga sudah mulai tenang dan tidak lagi chaos. Contoh dari kejadian sociohistoricaladalah perubahan kesempatan bagi perempuan dalam mengejar karir telah meningkat selama 30 tahun terakhir.

Chronosystem di definisakan sebagai menggambarkan derajat stabilitas atau perubahan dalam kehidupan seseorang. Termasuk kedalam chronosystem adalah perubahan komposisi keluarga, perubahan tempat tinggal dan perubahan pekerjaan orang tua. Contoh lain adalah dalam lingkungan yang lebih luas yaitu perang, kondisi ekonomi, dan gelombang imigrasi. Selain itu, perubahan dalam pola keluarga, misalnya semakin banyaknya para ibu yang bekerja (Papalia, 2008).

\section{Ontogenic System}

Untuk memperjelas pemahaman dan gambaran dinamika terjadinya usaha bunuh diri, peneliti memandang perlu melihat gambaran kondisi psikologis individu yang bisa mempengaruhi keputusannya dalam melakukan usaha bunuh diri. Kondisi psikologis ini tidak dibahas dalam teori ekologi Brofen-brenner. Oleh sebab itu faktor ontogenic system ditambahkan kedalam interaksi ke lima sistem tadi.

Menurut Belsky (1980), ontogenic systemlebih spesifik adalah mewakili demografik dan karakteristik pelaku yang bisa dijadikan faktor indikasi yang meningkatkan resiko tingkah laku bunuh diri.Ontogenic system bisa menjadi faktor yang mempunyai resiko yang tinggi dalam usaha bunuh diri ketika ia berinteraksi dengan faktor-faktor tambahan lainnya. Ontogenic systemterfokus pada faktor psikologis individu, sejarah, dan catatan medis yang membentuk respon mereka terhadap micro dan exosystem (Heise, 1998). Menurut Belsky, faktor ontogenic system yang signifikan dalam menjelaskan tingkah laku bunuh diri adalah depresi, putus asa, dan penggunaan obat-obatan terlarang.

\section{E. Depresi dan Bunuh Diri}

Depresi merupakan bagian dari gangguan mood. Gangguan mood mencakup berbagai gangguan emosi yang membuat seseorang tidak dapat berfungsi. Mulai dari kesedihan pada depresi hingga euphoria yang tidak realistis dan iritabilitas pada mania.

Gangguan depresi ada dua jenis yaitu depresi mayor atau unipolar dan distimik. Depresi mayor adalah kesedihan yang mendalam yang diikuti dengan gangguan tidur dan selera makan serta kehilangan energi dan harga diri. Depresi distimik termasuk kedalam gangguan mood kronis, yang simtomnya dianggap tidak memadai untuk menegakkan diagnosis depresi mayor ( Davison, 2006).

Depresi seringkali disebut sebagai faktor yang mempunyai korelasi tinggi pada berbagai usaha atau tindakan bunuh diri. Namun, tidak bisa dijadikan sebagai prediktor independent dalam bunuh diri karena bunuh diri merupakan bagian dari simtom mayor sementara masih banyak simtom lain yang yang menjadi indikasi gangguan ini (Maris, Berman \& Silverman, 2000).

Depresi yang dikombinasikan dengan beberapa faktor risiko yang lainnya akan meningkatkan resiko tingkah laku bunuh diri.Menurut Simon (1999), depresi merupakan kondisi emosional yang biasanya ditandai dengan kesedihan yang amat sangat, perasaan tidak berarti dan bersalah, menarik diri dari orang lain, tidak dapat tidur, kehilangan selera makan, hasrat seksual, dan minat serta kesenangan dalam aktifitas yang biasa dilakukan. Selain itu orang yang mengalami gangguan depresi sulit sekali memusatkan perhatian. Sulit bagi mereka memahami apa yang mereka baca dan mendengar pembicaraan orang lain. Cara bicara lamban, banyak jeda dalam mengungkapkan sesuatu, penggunaan katanya sedikit, dengan intonasi suara yang monoton. 
Banyak diantara mereka yang lebih menyukai kesendirian dan berdiam diri. Namun beberapa terlihat bersemangat, banyak bergerak, tidak bisa diam, meremas tangan dan selalu mengeluh. Bila penderita depresi mendapat masalah, mereka tidak bisa berpikir dengan jernih mengenai solusi yang akan diambil. Setiap momen merupakan hal yang berat dan kepalanya terus dipenuhi dengan pikiran menyalahkan diri sendiri. Beberapa bisa mengabaikan kebersihan dan penampilan diri serta mengeluhkan berbagai simtom somatik tanpa gangguan fisik yang jelas.Tampak tidak memiliki harapan, tidak ada inisiatif, selalu merasa khawatir, cemas dan pesimis sepanjang waktu (dalam Davison, 2006).

Simtom depresi menurut DSM IV

TR adalah sebagai berikut :

1. Mood sedih dan tertekan hampir sepanjang hari selama dua minggu atau kehilangan minat dan kesenangan dalam aktifitas yang biasa dilakukan, ditambah sekurang-kurangnya empat gejala berikut ini ;

2. Sulit tidur (insomnia); pada awalnya tidak dapat tidur; tidak dapat kembali tidur setelah terbangun ditengah malam, dan bangun pada dini hari; atau pada beberapa pasien keinginan tidur selama mungkin.

3. Perubahan kadar aktifitas, menjadi lemas (retardasi psikomotorik) atau terlalu bersemangat

4. Nafsu makan berkurang dan berat badan turun atau nafsu makan bertambah dan berat badan naik

5. Kehilangan energi dan sangat fatik

6. Konsep diri negatif, menuding dan menyalahkan diri sendiri, merasa tidak berarti dan merasa bersalah.

7. Mengeluh sulit berkonsentrasi atau terlihat sulit berkonsentrasi, seperti lambat dalam berpikir dan tidak dapat mengambil keputusan.

8. Pikiran tentang kematian dan bunuh diri yang terus menerus timbul.

Menurut Klerman, (1988b) prevalensi depresi semakin meningkat secara stabil selama pertengahan hingga akhir abad ke-20. Pada saat yang sama usia onset depresi menjadi semakin muda. Salah satu penyebabnya adalah terjadinya berbagai perubahan sosial yang terjadi dalam kurun waktu tersebut. Hal ini menyebabkan orang-orang muda saat ini banyak mengalami tantangan sementara dukungan untuk menghadapinya berkurang atau tidak ada, seperti dukungan keluarga besar atau keluarga inti yang memiliki ikatan kuat, kebiasaan-kebiasaan positif yang mulai menghilang dan agama banyak diabaikan (dalam Davison, 2006)

Menurut Freud (1963), depresi diciptakan pada awal masa kanak-kanak. Terjadi fiksasi pada periode ini membuat orang menjadi sangat tergantung pada orang lain dalam mempertahankan harga dirinya. Selanjutnya, Freud mengkaitkan dengan rasa duka setelah kehilangan seseorang yang dicintai karena kematian, perpisahan atau berkurangnya kasih sayang. Orang yang bersangkutan pertama meleburkan dirinya, mengidentifikasi dengan orang yang meninggalkannya sebagai usaha untuk mengembalikan kehilangannya tersebut. Freud mengatakan, secara tidak sadar orang tersebut menyimpan perasaan negatif terhadap orang yang dicintai. Pasien depresi menjadi objek kemarahan dan kebenciannya sendiri. Selain itu, ia tidak suka diabaikan dan merasa bersalah atas dosadosanya yang nyata atau yang dibayangkan terhadap orang yang meninggalkannya. Selanjutnya, kemarahan terhadap orang yang meninggalkannya terus menerus dipendam, berkembang menjadi proses menyalahkan diri sendiri, menyiksa diri sendiri, dan depresi yang berkelanjutan. Orang yang dependent/tidak mandiri diyakini sangat rentan dengan proses seperti ini. Menurut Nietzel \& Harris (1990) orang yang depresi memiliki ketergantungan tinggi dan cenderung menjadi depresi setelah ditolak (dalam Davison, 2006).

Beck (1967) mengatakan bahwa adanya proses berpikir yang salah yang 
menyebabkan orang mengalami depresi. Menurutnya orang depresi ketika masa anak dan remaja mengembangkan skemata yang negatif, yaitu memandang lingkungan secara negatif. Pandangan tersebut bisa disebabkan karena adanya peristiwa yang tidak menyenangkan misalnya, kehilangan orang tua, adanya tragedi yang terus menerus, penolakan sosial oleh teman sebaya, kritik para guru, atau sikap depresif orang tua. Setiap orang memiliki skemata, dan biasanya seseorang mengatur hidup dengan menggunakan rangkaian persepsi suatu peristiwa dengan skema tersebut. Pada orang depresi skemata negatifnya teraktivasi karena ia berhadapan dengan situasi yang sama ketika skema itu terbentuk. Lebih lanjut skemata negatif itu memicu dan dipicu oleh penyimpangan kognitif tertentu, yang membuat seseorang menerima realitas secara salah. Skema yang salah bisa membuat individu merasa salah sepanjang waktu, merasa gagal, merasa tidak berarti, merasa bertanggung jawab atas semua kegagalan dan kesalahan (Beck, 1967).

Individu yang mengalami depresi, memiliki sedikit jaringan sosial dan menganggap bahwa jaringan sosial hanya memberikan sedikit dukungan ( Keltner \& Kring, 1998 dalam Davison, 2006). Berkurangnya dukungan sosial dapat melemahkan kemampuan individu untuk mengatasi berbagai persitiwa hidup yang negatif dan membuatnya rentan terhadap depresi (Billings, Cronekite, \& Moos, 1983 dalam Davison, 2006). Kurangnya dukungan sosial kemungkinan disebabkan pada kenyataannya orang yang mengalami depresi bisa memicu reaksi negatif dari orang lain (Coyne,1976 dalam Davison, 2006).

\section{F. Putus asa / Hopelessness}

Putus asa adalah sikap yang negatif mengenai kejadian masa depan.Dalam Spirito \& Overholser, 2003) menurut Melges dan Bowlby (1969), hopelessness adalah harapan yang rendah untuk mencapai tujuan atau hilangnya keyakinan untuk mencapai kesuksesan. Selain itu, Beck,Weissman, Lester dan Trexler, (1974) seseorang yang hopelessness, disertai perasaan futility (sia-sia), kehilangan motivasi dan merasa dirinya adalah orang yang gagal

Studi mengenai hopelessness, depresi dan bunuh diri, menunjukkan hasil yang tidak konsisten. Studi yang dilakukan oleh Cole (1989) menemukan bahwa hopelessness khususnya pada laki-laki tidak berhubungan secara signifikan dengan ide untuk bunuh diri ketika depresi bisa dikontrol.

Sejalan dengan hal tersebut, hasil studi yang dilakukan oleh Lewinsohn, Rohde dan Seeley (1993) melaporkan bahwahopelessness dengan variabel psikososial lainnya tidak berkaitan dengan usaha bunuh diri jika faktor depresi bisa dikontrol. Berbeda halnya dengan penelitian yang dilakukan Mclaughlin, Miller dan Warwick (1996) menjelaskan bahwa hopelessness merupakan faktor yang cukup kuat dalam menentukan tingkah laku bunuh diri dibandingkan dengan depresi.

Menurut Beck (1985), orang yang merasa putus asa dengan kehidupannya mempunyai peluang lebih tinggi untuk melakukan bunuh diri.

Tekanan kehidupan bisa menjadi pemicu perasaan tidak berdaya dan putus asa. Beberapa bentuk depresi yang diakibatkan ketidakberdayaan (hopeless), diakibatkan oleh kondisi putus asa, suatu ekspektasi bahwa hasil yang dinginkan tidak akan terjadi atau situasi yang tidak di inginkan akan terjadi dan orang yang bersangkutan tidak bisa melakukan apapun untuk merubahnya (Abramson, Metalsky, \& Alloy, 1989 dalam Davison, 2006).

Menurut Mineka, Watson dan Clarck(1998) ekspektasi ketidakberdayaan (hopelesss) menimbulkan kecemasan, bila hal ini menjadi kepastian maka timbul sindrom dengan elemen depresi dan kecemasan. Jika kemungkinan yang dilihat mengenai terjadinya berbagai peristiwa 
negatif menjadi suatu kepastian, maka timbul keputusasaan (hopelessness)

Kehidupan yang penuh tekanan, langsung atau tidak akan menimbulkan krisis dalam kehidupan seseorang yang mengakibatkan depresi atau hopelessness (Spirito \& Overholser, 2003).

\section{G. Obat-obatan dan Alkohol}

Beberapa penelitian membuktikan bahwa penggunaan obat-obatan dan alkohol mempunyai korelasi yang signifikan dalam usaha bunuh diri. Berdasarkan otopsi pada pelaku yang melakukan bunuh diri ditemukan kadar alkohol yang tinggi. Alkohol atau obatobatan ini menguatkan keinginan usaha bunuh diri. Beberapa jam sebelum usaha bunuh diri biasanya mereka menggunakan alkohol atau obat-obatan untuk menguatkan usaha mereka. Peran alkohol sendiri sebagai faktor yang meningkatkan kesempatan bagi seseorang yang mempunyai ide untuk bunuh diri untuk mengaktualkan idenya tersebut menjadi tindakan nyata (Ayash-Abdo, 2002).

Penyalahgunaan obat dan alkohol comorbid dengan depresi meningkatkan terjadinya usaha tingkah laku bunuh diri. Hal ini terjadi karena alkohol menyebabkan judgment yang tidak tepat, menghambat kemampuan dalam problem solving, membatasi harapan dimasa depan, dan merubah suasana hati (mood). Penggunaan alkohol yang dimaksudkan untuk mengurangi depresi dan cemas justru malah meningkatkan depresi dan psychological distress. Penggunaan zat terlarang ini comorbid dengan gangguan mood, khusus nya depresi, meningkatkan sebanyak 50 kali resiko untuk melakukan usaha bunuh diri (Brent,1999; Shaffer, 1996). Kombinasi antara alkohol dengan gangguan tingkah laku (conduct disorders) juga merupakan faktor penting dalam meningkatkan resiko usaha bunuh diri, terutama pada laki-laki.

Alkohol jarang dipandang sebagai suatu obat kimia dan mempunyai efek yang disebut dengan efek bifase. Efek alkohol pada awalnya merangsang peminum merasakan suatu perasaan sosiabilitas dan nyaman yang ekspansif sejalan dengan meningkatnya kadar alkohol dalam darah. Namun ketika kadar alkohol sudah mencapai puncaknya dan mulai turun, alkohol berfungsi sebagai depresan dan peminum dapat mengalami peningkatan dalam berbagai emosi negatif. Alkohol dalam jumlah banyak menganggu proses berpikir kompleks, koordinasi motorik, keseimbangan, kemampuan berbicara, dan penglihatan pun melemah. Pada tahap intoksikasi beberapa individu menjadi depresi dan mengalami gejala putus zat (Davison, 2006).

Sejumlah penelitian menemukan bahwa alkohol mengurangi seluruh respon emosi positif dan negatif, namun tidak memiliki efek selektif pada berbagai emosi negatif sebagai respon terhadap berbagai situasi yang mengancam. Temuan lain mengindikasikan alkohol bisa mengurangi ketegangan dengan merubah kognisi dan persepsi (Curtin, 1998; Steele \& Josephs, 1990).

\section{H. Interaksi Semua Sistem}

Meskipun sistem-sistem yang ada tampaknya berdiri sendiri namun pada kenyataannya tidak bisa dipisahkan. Satu sama lain saling mempengaruhi dan berinteraksi. Individu tidak dilihat sebagai hasil dari perkembangan tetapi ikut membentuk perkembangan. Seseorang ikut membentuk karakteristik psikologisnya sendiri, bakat dan keterampilan, kemampuan (ability) dan temperamen.

Dalam konteks penelitian ini, individu berada di pusat lingkaran konsentrik, tidak dilihat sebagai bagian luar dari interaksi namun berperan dalam membentuk permasalahannya yang pada akhirnya memunculkan usaha bunuh diri. Selain dari karakteristik pribadi yang disampaikan Bronfenbrenner (1979), yaitu temperamen, talent dan skill yang dimiliki seseorang, peneliti menambahkan faktor individu dari Belsky (1980), yang mewakili demografik dan karakteristik 
pelaku yang bisa dijadikan indikasi yang meningkatkan resiko tingkah laku bunuh diri yaitu depresi, putus asa, obat-obatan dan alkohol. Karakteristik seseorang sangat mempengaruhi bagaimana ia merespon lingkungan dan menyelesaikan permasalahan hidup. Selain ikut membentuk, individu juga ikut merasakan bagaimana efek proses interaksi dirinya dengan lingkungan. Tekanan berat dalam kehidupan membuat sebagian orang bisa bertahan dan menjadikannya orang yang kuat dan tabah. Namun bagi sebagian lain mengakibatkan perilaku yang fatal salah satunya adalah perilaku usaha bunuh diri.

Seperti yang dikatakan Prayitno (2007) sulit menentukan penyebab orang melakukan bunuh diri, karena dengan permasalahan yang sama, tidak semua orang memilih bunuh diri menjadi solusi dari permasalahannya. Tindakan seseorang dalam usaha bunuh diri dipengaruhi oleh sistem yang yang berada dilingkungan. Mulai dari lingkungan terdekat misalnya keluarga, teman, teman kerja, sekolah, tetangga dan lain-lain. Bronfenbrenner, (1979) menyebutnya dengan microsystem. Microsystem mempengaruhi seseorang dalam usaha bunuh diri. Latarbelakang keluarga, merasa diabaikan, komunikasi yang terhambat antara anak - orang tua, kurangnya dukungan sosial, keterlibatan dengan sekolah yang tidak terjalin dengan baik, menimbulkan tekanan tersendiri bagi setiap orang.

Sistem berikutnya adalah mesosystem, yaitu gabungan dari satu atau dua setting. Kondisi rumah dan tempat kerja, atau kondisi rumah dengan sekolah, dari interaksi ini, bisa ditarik suatu pemahaman yang jelas mengenai bagai-mana individu yang sama, berinteraksi dalam berbagai situasi yang berbeda. Begitu juga dengan exosystem, meski individu tidak terlibat dan berinteraksi secara langsung namun pengaruhnya bisa berdampak pada seseorang. Misalnya, tekanan yang dialami orang tua dalam pekerjaan akan mempengaruhi bagaimana ia bersikap terhadap anak ketika di rumah. Menurut
Ayash-Abdo (2002) dalam exo-system, media memegang peran penting dalam mempengaruhi usaha bunuh diri. Perannya dalam menyebarkan berita mengenai bunuh diri secara besar-besaran, disadari atau tidak turut mempengaruhi keputusan seseorang dalam melakukan usaha bunuh diri.

Selain itu, dalam kehidupan seseorang tidak jarang ia mengalami perubahan yang dianggap signifikan oleh masing-masing individu mengalami transisi sebagai akibat dari perubahan yang dialaminya. Misalnya, perceraian orang tua, perpindahan tempat tinggal, sekolah, pekerjaan orang tua dll. Untuk menjelaskan hal ini, Bronfenbrenner menyebutnya dengan chronosystem. Chronosystem merupakan gambaran penyesuaian yang harus dilakukan individu ketika menghadapi suatu perubahan yang terjadi dalam hidupnya

Faktor budaya berupa penilaian, konsep mengenai bunuh diri bagi masayarakat tertentu juga mempengaruhi bagaimana usaha bunuh diri dilakukan. Dalam budaya yang menganggap bunuh diri adalah suatu tindakan yang dihormati karena membela keyakinan keberagamaannya, membela kehormatan keluarga, harga diri dan lain-lain membuat tindakan bunuh diri dianggap normal bahkan terpuji. Agama tertentu yang meyakini bunuh diri sebagai jalan untuk bertemu dengan orang yang dicintai, sebagai cara untuk menunjukkan kesetiaan istri terhadap suami membuat tindakan ini menjadi hal yang biasa, bahkan di anggap kebaikan. Sebaliknya budaya yang menganggap bunuh diri sebagai tindakan yang negatif, membuat masyarakat memandang hal ini sebagai perilaku yang memalukan.

Budaya yang ada di masyarakat merupakan hasil interaksi antara semua individu yang ada dalam lingkungan, selama bertahun-tahun bahkan lebih lama lagi. Adanya belief, nilai dan norma dipengaruhi oleh masing-masing individu yang berinteraksi dalam lingkungan kecil mereka, yaitu rumah, tetangga, sekolah 
dan lain-lain. Sebaliknya, hasil interaksi ini akan kembali mempengaruhi masingmasing individu dalam berinteraksi dengan lingkungan.

\section{METODE PENELITIAN}

\section{Desain Penelitian}

Untuk mencapai tujuan penelitian, perlu mengungkapkan kompleksitas permasalahan yang dihadapi partisipan yang mendorong mereka untuk melakukan tindakan usaha bunuh diri oleh karena itu pendektan penelitian yang dipilih adalah kualitatif dengan metode studi kasus.

\section{Subjek Penelitian}

\section{Metode Pemilihan Subjek Penelitian}

Teknik mendapatkan partisipan dengan teknik snowball. Pencarian diawali dengan menyampaikan informasi dari mulut-kemulut, melalui beberapa lembaga konsultasi psikologi, kerumah sakit dan kepada beberapa teman. Subjek pertama adalah diperoleh dari teman. Subjek kesua adalah klien di sebuah klinik psikologi, keluhan awalnya adalah masalah dengan suami. Partisipan kedua, subjek mendatangi peneliti dan menyatakan kesediaannya untuk dijadikan partisipan penelitian.

\section{Karakteristik Subjek penelitian}

Karakteristik partisipan untuk penelitian ini adalah :

1. Pernah melakukan usaha bunuh diri.

2. Jarak antara usaha bunuh diri dengan wawancara penelitian tidak lebih dari dua tahun.

3. Usaha bunuh diri dilakukan dengan niat ingin mati namun masih bisa diselamatkan.

\section{Jumlah Subjek Penelitian}

Dari lima partisipan yang penulis temukan, hanya dua yang memenuhi priteria subjek penelitian. Selanjutnya partisipan penelitian melibatkan significant other dari pelaku usaha bunuh diri.

\section{Metode Pengumpulan Data}

Wawancara dan Observasi

\section{A. Alat bantu Penelitian}

Alat perekam dan alat tulis.

\section{B. Metode Analisis Data}

Setelah semua data terkumpul, selanjutnya akan dilakukan analisis data yang diawali dengan mencatat semua hasil wawancara secara verbatim. Kemudian melakukan koding pada materi yang telah terkumpul dengan tujuan untuk mengorganisasi dan mensistematisasikan data secara lengkap dan mendetil sehingga didapat gambaran lengkap mengenai permasalahan. Data hasil observasi men-jadi data tambahan yang digunakan untuk menganalisis data secara keseluruhan.

\section{Prosedur Pelaksanaan Penelitian}

\section{A. Tahap Persiapan}

Sebelum penelitian dilakukan, peneliti melakukan persiapan, tahapannya adalah:

1. Menemukan permasalahan

2. Menggali informasi dan data yang diperlukan dengan melakukan penelusuran di berbagai media yaitu televisi, koran dan internet

3. Menggali dan memahami konsep tentang tema yang telah ditentukan sebagai referensi dalam penelitian

4. Mencari literatur ke perpustakaan, $e$ book dan jurnal penelitian

5. Mencari partisipan sesuai dengan kriteria yang telah ditetapkan

6. Menyiapkan pedoman wawancara

\section{B. Tahap Pelaksanaan}

1. Melakukan wawancara terhadap partisipan dan significant others.

2. Menuliskan hasil wawancara secara verbatim

3. Mengkoding data\& mengorganisasi data

4. Melakukan analisis data intra dan inter kasus

5. Membuat kesimpulan dan saran. 


\section{HASIL DAN PEMBAHASAN}

\section{A. Hasil Penelitian Partisipan Pertama}

Hubungan Mawar dengan ayah yang kurang dekat serta perkawinan antara ibu dan ayah yang bermasalah membuat tidak terbangunnya komunikasi yang terbuka diantara mereka. Menurut Adam dan Brent (1994) indikator keluarga bermasalah yang paling banyak menimbul-kan usaha bunuh diri adalah faktor komunikasi dan pola hubungan orang tua dan anak yang kurang dekat. Kebutuhan Mawar akan afeksi dan dukuangan emosional dari orang terdekatnya cukup kuat. Sementara sumber afeksi yang Mawar butuhkan yaitu dari ayah tidak bisa ia dapatkan. Menyebabkan tumbuhnya perasaan rindu sekaligus benci terhadap figur ayah. Kebutuhan akan perhatian dan kasih sayang terutama dari sosok ayah membuat Mawar merasa semakin tertekan ketika melihat hubungan antara teman dengan ayah mereka. Semakin lama ia semakin merasa di abaikan. Hal ini memicu perasaan cemas yang semakin lama semakin sering muncul.

Begitupun hubungan dengan ibu, meskipun dirasakan baik-baik saja namun, kesibukan ibu membuat frekuensi bertemu menjadi sedikit. Hal ini menyebabkan Mawar seringkali merasa kesepian dan cemas.

Di sisi lain, perkawinan yang bermasalah atau penuh konflik menurut Adam dan Brent (1994), akan mempengaruhi kepribadian anak. Begitupun dengan Mawar, permasalahan antara ayah dan ibu, membuat ia menjadi tertutup dan tidak assertif dalam mengungkapkan perasaannya. Hal ini di rasakan Mawar terutama setelah ia remaja ketika ia mulai berinteraksi dengan teman sebayanya. Ia tidak punya teman dekat/sahabat, teman yang bisa diajak berbagi dalam berbagai situasi.

Perasaan cemas terus ia rasakan sampai ia dewasa. Bahkan setelah ia menikah perasaan cemas kerap kali muncul. Sikap suami yang kurang perhatian dan kurang peka membuat komunikasi diantara meraka tidak terbangun dengan baik. Hal ini membuat Mawar merasa teringat kembali pada sosok ayah.

Sikap dingin suami memicu perasaan diabaikan dan membuat perasaan cemas semakin kuat. Pengaruh nilai-nilai agama dan budaya mengenai peran seorang istri yang baik, membuat ia semakin terbebani. Keterpaksaan dalam menjalankan peran sebagai istri dalam melayani suami membuat ia merasa bukan lah istri yang baik. Ia kurang asertif dalam mengungkapkan keinginannya terhadap suami. Komunikasi yang tidak sehat antara Mawar dengan suami membuat banyak permasalahan yang tidak terselesaikan dengan tuntas. Termasuk dalam urusan ekonomi keluarga. Mawar merasa menanggung semua permasalahn sendirian. Dukungan emosional dari suami yang ia harapkan tidak ia peroleh. Hilangnya dukungan emosional atau emotional responsive yang dibutuhkan ketika menghadapi permasalahan mengakibatkan tekanan itu semakin menumpuk dan pada akhirnya melampaui toleransi stress nya. Sebagi trigger adalah kelahiran anak ketiga yang memicu depresi dan hopelessness yang terus menerus dan berkepanjangan. Hilangnya dukungan emosional atau emotional responsive yang dibutuhkan ketika menghadapi permasalahan menurut Ayyash-Abdo (2002) bisa menjadi penyebab orang melakukan usaha bunuh diri.

Karakter Mawar yang pendiam dan tertutup membuat tekanan psikologis yang ada selama ini tidak terungkap. Sikap suami yang dirasakan mengabaikannya memunculkan kekesalan, marah, perasaan bersalah sekaligus putus asa dan tidak berdaya. Ketika beban psikologis dirasakan semakin berat ditambah dengan kondisi depresi dan tidak berdaya membuatnya tidak bisa berpikir objektif. Usaha untuk mendapatkan perhatian suami ia lakukan tanpa ia sadari yaitu dengan mengeluhkan berbagai penyakit namun tidak disertai gangguan fisik. 
Menurut Maris, Berman \& Silverman (2000), depresi berkorelasi tinggi dengan usaha bunuh diri. Mawar merasakan kesedihan yang terus menerus, menarik diri, tidak dapat tidur, dan merasa tidak berarti dan mulai muncul godaan untuk bunuh diri. Menurut Simon (1990) perilaku itu adalah simtom yang biasa terjadi pada orang yang depresi. Menurut Freud depresi diciptakan sejak masa awal anak-anak. Rasa duka karena kehilangan sumber afeksi membuat seseorang terfiksasi pada fase itu. Secara tidak sadar orang akan menyimpan perasaan negatif terhadap orang yang dicintainya. Seperti yang terjadi pada Mawar, ia merindukan sekaligus membenci ayahnya yang tanpa sadar ia simpan sampai ia dewasa. Perasaan ini muncul kembali ketika ia menghadapi suami yang dirasakannya banyak kesamaan dengan ayah. Ia merasa tertolak dan terabaikan ketika suami tidak memperhatikan dan kurang responsif dengan kondisinya.

Menurut Beck (1967) orang yang mengalami depresi pada saat anak-anak dan remaja akan mengembangkan skema negatif. Pengalaman negatif masa kecil dengan ayah menimbulkan skema negatif terhadap sosok ayah yang ia asosiasikan dengan figur suami. Skema ini teraktivasi ketika berhadapan dengan situasi yang sama ketika skema itu terbentuk. Ketika ia berhadapan dengan suami yang ia anggap mirip ayah membuat persaan cemas dan tertekan semakin kuat.

Peran media dalam menuntunnya untuk menemukan cara yang tepat dalam memilih cara bunuh diri ternyata besar. Ia menemukan ide bagaimana cara mengakhiri hidup berdasarkan informasi yang ia lihat dan baca di berbagai media. Rasa keberagamaan yang sebelumnya ada sudah tidak banyak berpengaruh ketika dorongan bunuh diri semakin besar.

Depresi dan hopelessness yang terus menerus membuat cara berpikirnya menjadi tidak objektif. Ia merasakan semuanya terasa sempit dan tidak melihat celah lain dalam menyelesaikan permasalahan selain bunuh diri. Penihilan terhadap diri sendiri semakin membesar. Cara berpikirnya sudah tidak rasional. Sampai akhirnya keputusan bunuh diri ia lambil meski tidak mengakibatkan kematian. Karena pemahaman yang terbatas mengenai metode bunuh diri, membuat cara yang dipilih tidak fatal sehingga tidak sampai mengakibatkan kematian.

\section{B. Hasil Penelitian Partisipan Kedua}

Kekerasan fisik yang dilakukan orang tua, menyebabkan hubungan komunikasi diantara mereka tidak terbangun dengan baik. Ayah kurang memberikan penghargaan dan pengakuan kepada Melati. Di samping itu, ibu tidak sabaran dan kurang peka dengan kehidupan emosi membuat banyak masalah yang lepas dari pengetahuan orang tua. Hal ini juga berdampak pada, Melati kehilangan sumber afeksi dan dukungan dalam menghadapi masalah. Rumah yang penuh konflik antara ayahibu dan antara saudara membuat Melati tidak nyaman dan seringkali mengganggu aktifitasnya terutama setelah remaja.

Setelah remaja ketika permasalah-an yang dihadapi lebih kompleks, Melati yang tertutup tidak bisa mendapatkan dukungan emosional dari teman dalam menyelesaikan permasalahannya. Untuk menutupi permasalahannya ia melakukan penyangkalan atas masalah yang menimpanya, berupaya aktif dalam berbagai aktifitas sekolah dengan tujuan untuk melupakan permasalahan. Meskipun cara ini tidak efektif dalam menyelesaikan masalah. Melati berupaya ingin tampil baik dihadapan teman. Di sisi lain, ia kurang percaya diri dengan kemampuannya, didukung daya dobrak yang kurang kuat dalam menghadapi masalah. Selain itu, ia tidak terlatih untuk mengendalikan keinginan.Hal tersebut memperkuatnya untuk terus melakukan pencurian.

Ketika pencurian diketahui oleh pihak sekolah, ia menjadi malu. Rasa bersalah muncul seiring dengan kesadaran 
bahwa perbuatannya adalah salah dan dosa. Nasehat dari ustadz-ustadz-nya membuat rasa bersalah semakin besar. Ditambah lagi dengan permasalahan rumah yang masih membayanginya, kondisi ayah, konflik di keluarga serta incest yang dilakukan kakak. Semua itu memperkuat permasalahan yang di alami Melati. Ia semakin tidak berdaya, rasa bersalah dan dosa yang semakin besar membuat ia mencari jalan untuk lari dari masalah. Godaan bunuh diri semakin besar, dengan "bantuan" media ia bisa menemukan cara yang tepat dalam menyelesaikan masalahnya dengan memilih cara bunuh diri yang dianggapnya tepat. Bagan dibawah ini menggambaran dinamika terjadinya usaha bunuh diri pada Melati.

\section{Pembahasan Inter Subjek}

Seperti yang dikatakan oleh Prayitno (2007), tidak mudah menemukan penyebab orang melakukan bunuh diri. Karena pada kondisi yang sama, bahkan lebih berat, ada orang yang tidak melakuan usaha bunuh diri.

Hal ini disebabkan karena setiap orang memiliki latarbelakang, pengalaman dan persepsi yang berbeda dalam memandang permasalahan yang sama. Karenanya penyebab orang melakukan usaha bunuh diri tidak bisa hanya dipandang dari satu sisi saja. Untuk memahami secara keseluruhan perlu cara pandang yang lebih komprehensif, selain faktor pribadi, masalah lingkungan menjadi hal penting untuk digali.

Peneliti menemukan bahwa usaha bunuh diri disebabkan oleh berbagai faktor yang saling berkaitan. Microsystem, mesosystem, exosystem, macrosystem, chronosystem dan ontogenic system. Masing-masing sistem memberikan konstribusi bagi terjadinya usaha bunuh diri yang dilakukan oleh kedua partisipan.

Berawal dari lingkungan yang terdekat tempat dimana individu berinteraksi langsung atau Microsystem. Dari sini peneliti memperoleh data bahwa kedua partisipan mempunyai masalah dengan keluarga yaituhubungan dengan ayah, ibu, perkawinan orang tua yang penuh konflik, komunikasi yang minim, hilangnya rasa aman dalam rumah dan kekerasan fisik. Hilangnya peran orang tua sebagai sumber afeksi, tempat kembali seseorang ketika mendapatkan masalah dan tempat mencari dukungan dan perlindungan ketika merasa terancam. Sementara itu, Mawar mempunyai masalah dengan suami. Hubungan dengan suami yang penuh konflik dan kurang terbangunnya komunikasi yang sehat diantara mereka. Untuk kasus Melati, selain masalah dengan orang tua, ia juga mengalami incest yang dilakukan oleh kakak nya yang kedua.

Sesuai dengan hasil penelitian yang telah dilakukan oleh Perkins dan Hartless (2002) kehidupan perkawinan yang penuh konflik, kekerasan seksual, kekerasan fisik, kurangnya dukungan orang tua, keterlibatan dengan teman yang minim menjadi penyebab yang signifikan dalam memunculkan perilaku bunuh diri. Semua faktor tadi berinteraksi dengan faktor pribadi atau ontogenic system.Hal itu, menjadi kombinasi yang "tepat" dalam memunculkan perilaku bunuh diri.

Hubungan dengan teman sebatas tempat untuk bersosialisasi.Teman belum menjadi pihak yang bisa memberikan dukungan emosional dan berafiliasi ketika ada masalah, atau tempat berbagi dalam banyak hal.Bagi Melati sekolah menjadi tempat untuk melupakan permasalahan, dengan aktif dalam bebagai aktifitas yang membuat dia dikenal banyak orang.

Menurut Aseltin, Gore dan Colten (1998), rendahnya dukungan sosial dari peers berkaitan dengan kecenderungan untuk untuk bunuh diri dan tingkah laku bunuh diri.

Permasalahan yang ada di microsystem bisa menjadi stressor yang semakin besar ketika masing-masing setting berinterelasi atau disebut dengan mesosystem. Membuat masalah yang dihadapi partisipan menjadi semakin berkembang. 
Memunculkan masalah-masalah baru. Misalnya hubungan antara ayah dan ibu, membuat Mawar merasa semakin terabaikan. Pada kasus Melati, ia mendapatkan kekerasan fisik dari orang tua dan kekerasan seksual dari kakak membuat ia merasa semakin tertekan dan tidak nyaman berada di rumah.

Faktor exosystem yang ditemukan pada kasus ini adalah pengaruh pekerjaan ibu bagi Mawar. Ibu yang sibuk bekerja membuat Mawar menjadi kesepian, merasa takut dan cemas. Sementara itu, masalah media membuat mereka berdua mengetahui cara yang "tepat" bagaimana mengakhiri hidup.

Ketika orang tidak bisa mengembangkan kedekatan emosi yang sehat didalam rumah membuat seseorang berkurang kebanggaaan atas diri (Orbach, 1988). Ketika hal ini berinteraski dengan ontogenic system yaitu kondisi depresi atau hopelessness. Kemudian secara pribadi partisipan termasuk orang yang tertutup, tidak assertifhal ini membangkitkan kecenderungan untuk melakukan bunuh diri.

Faktor agama dan budaya turut memberi konstribusi yang signifikan pada kedua partisipan. Untuk Mawar, nilai-nilai agama selaras dengan nilai budaya yaitu keyakinan bahwa seorang istri harus bisa menjalankan fungsinya dengan benar sesuai tuntutan agama namun di sisi lain, suami tidak merespon usaha yang telah dilakukannya. Membuat Mawar menjadi konflik, yang berakibat pada menyalahkan diri sendiri dan perasaan berdosa. Bagi Melati, keyakinan bahwa orang yang pernah mengalami kekerasan seksual, adalah memalukan, aib dan akan mendapat permasalahn dengan perkawinan terus menerus mengganggunya terutama setelah ia remaja. Ditambah lagi dengan keyakinan tentang nilai agama bahwa mencuri merupakan dosa besar membuat ia semakin tertekan. Selain harus menaggung rasa malu ia juga menanggung perasaan berdosa.
Dari chronosystem peneliti menemukan bahwa perjalanan hidup seseorang yang terus berlanjut dan berkembang selain memunculkan aspek positif yaitu semakin matangnya seseorang juga memunculkan masalah negatif. Untuk kasus dalam penelitian ini, permasalahan yang muncul sejak kecil dan tidak tuntas pada fase itu, bergulir seperti bola salju. Semakin lama permasalahan semakin membesar dan merusak banyak hal dalam diri orang tersebut.

Faktor individu menurut Bronfenbrenner (1979) dan Ontogenic system menurut Belsky (1980) yang mencakup karakter pribadi dan aspek psikologis yang membuat seseorang rentan terhadap tindakan bunuh diri adalah depresi dan hopelessness. Partisipan pertama orangnya tertutup, tidak asertif, depresi dan hopelesss. Partisipan kedua, peneliti menemukan bahwa Melati orangnya tertutup, rendah diri, kurang ulet, dan hopeless. Hal itu yang turut memberikan kontribusi pada usaha bunuh diri yang meraka lakukan.

\section{SIMPULAN DAN SARAN}

\section{Simpulan}

Berdasarkan hasil penelitian,kesimpulannya adalah :

1. Microsystem dan mesosystem yang muncul dari dua partisipan adalah masalah dengan orang tua, konflik perkawinan ayah-ibu, konflik dengan suami, kekerasan seksual, kekerasan fisik, konflik dengan saudara, hubungan dengan teman dan sekolah. Faktor ini berinterrelasi memunculkan tekanan psikologis yang berat bagi partisipan.

2. Faktor microsystem khususnya keluarga bermuara dari kondisi keluarga yang tidak kondusif untuk tumbuh kembang partisipan sehingga mereka tidak punya cukup keterampilan dalam menyelesaikan permasalahan yang dihadapinya. Menurut Rubenstein, Heeren, 
Housman, Rubin \& Stecheir (1989, dalam Kidd, Davidson, King, \& Shahar, 2006) bahwa disfungsi keluarga berpengaruh secara signifikan terhadap tindakan usaha bunuh diri. Disfungsi keluarga yang dialami oleh Melati dan Mawar selain membuat mereka merasa tertekan juga membuat mereka tidak mempunyai banyak kesempatan untuk mengembangkan kemampuan dalam memecahkan permasalahan dengan efektif ketika ia berinteraksi dilingkungan sosial yang lebih luas. Bagi Melati disfungsi keluarga selain mengakibatkan ia melakukan tindakan pencurian yang dilakukan secara berulang juga membuat ia menjadi korban incest. Masalah ini membuatnya merasa bersalah, menyalahkan diri sendiri, merasa putus asa dan khawatir dengan masa depannya. Bagi Mawar disfungsi keluarga menumbuhkan perasaan marah, menyalahkan diri sendiri, putus asa, khawatir, merasa lelah (fatigue) dan memicu annihilation sehingga akhirnya ia bunuh diri. Kalau melihat hal tersebut, komponen dalam perilaku bunuh diri yang disampaikan oleh Menninger (dalam Shneidman, 1970) yaitu the wish to kill, the wish to be killed dan the wish to die terpenuhi. Selain hal tadi, dalam kasus Melati, terlihat ia menyalahkan orang tua atas permasalahan yang menimpanya dan selalu mempertanyakan "nasib" yaitu ketika menjadi korban incest.

3. Dari Exosystem ditemukan ma-salah mengenai pekerjaan orang tua dan pengaruh media. Pekerjaan ibu bagi Mawar membuat ia merasa semakin merasa kesepian dan tanpa disadari menambah rasa cemas yang sebelumnya sudah ada akibat interaksi yang tidak sehat dengan ayah. Pengaruh media memberikan idebagi keduanya untuk menemukan cara yang tepat dalam mengakhiri hidup.

4. Dari Macrosystem diketahui konstribusi keyakinan pada nilai-nilai agama dan keyakinan terhadap nilai-nilai budaya terhadap usaha bunuh diri yang dilakukan kedua partisipan. Keyakinan pada nilai-nilai agama, untuk kasus Mawar dan Melati justru membuat mereka terdorong untuk melakukan bunuh diri. Pada saat seseorang berada dalam tekanan (perasaan malu yang he-bat, cemas, takut dan emosi negatif lainnya) nasehat agama yang diberikan dengan cara yang kurang tepat, semakin menambah bebanyang kuat bagi keduanya. Oleh karenanya, dalam kondisi seperti itu, penanaman keyakinan pada nilai-nilai agama perlu disertai dengan mempertimbang-kan kondisi psikologis yang bersangkutan sehingga bisa dilakukan dengan tepat sasaran. Seperti yang dikatakan Shneidman (1970), tidak benar ketika seseorang menjadi pengikut agama tertentu atau larangan agama untuk melakukan usaha bunuh diri serta merta menghentikan niat mereka untuk melakukan usaha bunuh diri. Artinya tidak berarti ketika seseorang meyakini larangan agamanya untuk bunuh diri menjadikannya tidak melakukan usaha bunuh diri. Hal ini terjadi pada kedua partisipan, meskipun keduanya meyakini bahwa bunuh diri adalah dosa namun tidak memberhentikannya untuk tidak melakukan usaha bunuh diri.

Ketika Melati ketahuan mencuri, membayangkan berita sudah tersebar keseluruh sekolah, sudah menjadi pukulan telak bagi harga dirinya dan menimbulkan rasa bersalah yang besar. Di tambah dengan nasehat ustadz yang dipahami Melati semakin menguatkan bahwa dia bersalah dan telah melakukan perbuatan dosa. Bagi Melati yang kondisi ontogenicsystem nya sedang tidak stabil, membuat ia tidak bisa berpikir dengan objektif. Ia salah memaknai nilai agama. Nilai agama tidak dimaknai sebagai "rem" untuk tidak melakukan kesalahan. Namun sebaliknya, hal itu semakin 
menguatkan bahwa ia telah melakukan kesalahan. Sehingga perasaan bersalah dan berdosa semakin besar.Hal ini semakin menenggelamkan dia pada permasalahan dan merasa putus asa dengan kondisi yang dihadapinya.

Hal itu terjadi bukan karena nilai agama atau budayanya yang salah tetapi cara yang dilakukan dalam menyampaikan nilai-nilai tersebut kurang tepat dengan kondisi partisipan. Akhirnya ia melakukan self-derogation (mencela/menghujat diri sendiri) yang mendorong keinginan untuk bunuh diri semakin besar. Seperti yang disampaikan oleh Shagle dan Barber bahwa selfderogation (mencela diri sendiri) berkorelasi dengan tindakan dan ide bunuh diri. Self-derogation sendiri adalah efek dari faktor-faktor sosial yaitu keluarga, sekolah, peers, dan agama (dalam Jin \& Zhang, 1998).

5. Di sisi lain, bisa dilihat pengaruh keyakinan pada agama bagi keduanya. Keyakinan ini yang menghentikan kedua partisipan untuk tidak meneruskan usaha bunuh diri. Setelah mereka lebih tenang dan ontogenic system nya lebih stabil, mereka bisa merenungi kembali keyakinan mereka.

6. Dari Chronosystem peneliti menemukan bahwa perkembangan partisipan sepanjang kehidupan-nya memberikan pengaruh pada fase kehidupan berikutnya. Ketika permasalahan tidak tuntas pada satu fase akan menyebabkan pemasalahan pada fase selanjut-nya. Hal ini saling berinteraksi dengan ontogenic system seseorang yaitu depresi, hopeless-sness, dan karakter individu lainnya sehingga muncul tindakan usaha bunuh diri.

7. Hal lain yang peneliti lihat dari hasil penelitian adalah adanya ambivalensi dari masing-masing partisipan ketika melakukan usaha bunuh diri. Perilaku bunuh diri yang dilakukan Mawar maupun Melati kemungkinan adalah attention seeking. Seperti yang dikatakan Shneidman (1970) bahwa sebagian orang yang berniat melakukan usaha bunuh diri tidak yakin kalau mereka benar-benar ingin mati. Kondisi ini mematahkan mitos bahwa orang yang ingin bunuh diri betul-betul ingin mati. Hal ini juga dikatakan oleh Maris, Berman, dan Silverman (2000) dalam kelompok non fatal suicide atau attempted suicide terdapat orang yang ambivalent. Satu sisi ia melakukan usaha bunuh diri namun tidak sepenuhnya menginginkan kematian.

Untuk kasus Mawar, cara yang dipilih untuk bunuh diri tidak fatal. Ketika melakukan usaha bunuh diri, empat dari enam kali usaha bunuh diri dilakukan dengan sepengetahuan orang-orang terdekatnya yaitu suami dan ibunya. Selain itu, dalam usaha bunuh dirinya baik Mawar maupun Melati memilih tempat yang mudah diketahui oleh orang lain. dihadapi dan ia butuh cara yang benar-benar bisa membuat dirinya diperhatikan. Namun di sisi lain ia tidak mau mati.

8. Kelemahan penelitian ini adalah peneliti kesulitan mendapatakan data dari significant others yang tepat. Misalnya untuk kasus Mawar significant others yang penting adalah suaminya, namun suami tidak bisa dijadikan sumber informasi karena menolak untuk di wawancara.

9. Selain itu partisipan kurang homogen. Meski dua-duanya sudah masuk kategori dewasa namun rentang usia antara partisipan pertama dengan kedua agak jauh, serta status perkawinan yang berbeda.

\section{Saran}

Saran praktis:

1. Untuk Mawar dan Melati, terus melakukan konseling. Untuk Mawar, konseling dengan melibatkan suami

2. Mawar dan Melati terus mengembangkan hobi menulis sebagai salah satu bentuk katarsis 


\section{Saran metodologis :}

1. Melibatkan lebih banyaksignificant othersyang terlibat langsung dalam setiap permasalahan yang dihadapi partisipan.

2. Menambah prosedur pengambilan data tidak hanya dengan interviu tetapi dengan pemeriksaan psikologi sehingga bisa didapat gambaran lengkap mengenai kepribadian orang tersebut. Atau mengukur depresi dan hopelessness sehingga menjadi lebih akurat dan terukur.

3. Mencoba untuk lebih mengejar informasi mengenai adanya kemungkinan ambivalensi dari pelaku bunuh diri. Terutama dari pelaku yang terlihat benar-benar ingin mati.

\section{DAFTAR PUSTAKA}

Aseltin, R.H., Gore, S.,\& Colten, M.E. (1998). The Co-occurrence of Depression and Substance Abuse in Late Adolescence.Journal of Development and Psychopathology, 10, 549-570. Diunduh 6 Februari 2010

Ayyash-Abdo, H. (2002). Adolescent suicide : An Ecological Approach. Published on line in Wiley InterScience.Diunduh 22 Februari 2009 dari www.interscience.wiley.com

Beck, A.T. (1967).Depression : Causes and Treatment. Philadelphia: University of Pennsylvania Press

Belsky, J. (1980). Child maltreatment: An ecological integration. Journal of Development and Psychopathology,35, 320-335. Diunduh 6 Februari 2010

Berns, M.R. (1997). Child, Family, School, Community Socialization and Support. 4 edition. New York : Holt, Reinehart \& Winston. Inc.

Bronfenbrenner, U. (1979). The Ecology of Human Development: Experiments by Nature and Design. Cambridge, MA: Harvard University Press
Canter, D., Giles, S., \&Nicol, C. (2004).Suicide Without Explicit Precursors: A State Of Secret Despair?Journal for Investigative Psychology and Offender Profilling 1: 227-248. Published on line in Wiley InterScience.Diunduh 22 Februari 2009 dari www.interscience.wiley.com

Carson, C.R., \& Butcher, J. (1992).Abnormal Psychology and Modern Life.Ninth Edition.New York: HarperCollins Publisher Inc

Cole, D.A. (1989). Psychopathology of Adolescent Suicide: Hopelessness, Coping Beliefs, and Depression. Journal of Abnormal Psychology, 98, 248-255. Diunduh 3 Febuari 2010

Darmaningtyas. (2002). Pulung Gantung. Jogjakarta: Salwa Press

Davison, G. C., Neale.M.J.,\& Kring, M.A. (2004).Abnormal Psychology. 9 Edition. Washington DC: John Wiley \& Sons.

Douglas. M. (1967). The Social Meanings of Suicide. Princeton, New York: Princeton University Press

Durkheim, E. (1951). Suicide.London: Routledge \& Kegan Paul Ltd.

Forwood, S.R., Asarnow, R.J., \&Huizar, P.D. (2007). Suicide Attempts Depressed Adolecents in Primary Care. Journal of Clinical Child and Adolescents Psychology, vol. 31, No 1, 48-58. Diunduh 22 Februari 2009.

Ghaziuddin,N., KingC.A., Naylor, W.M., \&Ghaziuddin, M. (2002). Anxiety Contributes to Suicidality in Depressed Adolescent. Journal Depression and Anxiety 11:134-138. Wiley-Liss, Inc.Diunduh 1 Maret 2009

Heise, L. (1998). Violence against women: An integrated ecological framework. Violence Against Women, 4, 262290. Di unduh 1 Maret 2009

Jin, S., \&Zhang, J. (1998). Effects of Physical and Psychological WellBeing on Suicidal Ideation. Journal 
of Clinical Psychology, vol 54(4), 401-413. Diunduh 1 Maret 2009

Karlsson, L., Pelkonen, M., Heila, H., Holi, M., \& Kiviruusu, O. (2007). Diffrences in The Clinical Characteristics of Adolecent Depressive Disorder. Diunduh 3 Maret 2009 dari Wiley InterScience (www.interscience.wiley.com).

Kidd, S., Davidson, L., King, R.A. \& Shahar, G. (2006). The Social Context of Adolescent Suicide Attempt : Interactive Effect of Parent, Peer and School Social Relation. ProQuest Psychology Journals. Pg. 386. Diunduh 18 Juni 2009.

Lewinsohn, P.M., Rohde, P., \& Seeley, J.R. (1993). Psychosocial Characteristics of Adolescents with a History of Suicide Attempt. Journal of the American Academy of Child and Adolescent Psychiatry, 32, 6068. Diunduh 3 Februari 2010

Maris, R.W., Berman, L., \& Silverman, M. (1970) The Psychology of Suicide. New York : Science House

Maris,R.W. (2000). Comprehensive Text Book of Suicidology. New York: The Guilfrod Press

McLaughlin, J., Miller, R., \& Warwick, H. (1996). Deliberate Self-Harm in Adolescents: Hopelessness, Depression, and Problem Solving. Journal of Adolescence, 19, 523532. Diunduh 3 Februari 2010

Miles, H. (1994). An Expanded Sourcebook : Qualitative Data Analysis. $2^{\text {nd }}$ Edition.London: Sage publication. Inc.

Mussen, C. (1983). Handbook of Child Psychology. 4 Edition. Washington DC: John Wiley \& Sons. Inc.

Orbach, I. (1988). Children Who Don't Want to Live : Understanding and Treating The Suicidal Child. San Fransisco: Jossey-Bass Publisher.

Papalia, E.D., Olds, W.S., \& Feldman, D.R. (2008) Human Development. New York:Mc Graw Hill
Patton, M. Q. (1990). Qualitative Evaluation and Research Methods. $2^{\text {nd }}$ Edition. Newbury Park, CA: Sage Publication, Inc.

Peorwandari, K. (2007) Pendekatan Kualitatif untuk Peneltian Perilaku Manusia. Depok: LPSP3 Fakultas Psikologi Universitas Indonesia

Randell, P.B., Wang, W.L., Herting, R.J., \&Eggert, J.J. (2006). Family Factors Predicting Categoriesof Suicide Risk. Journal of Child and Family Studies.Vol. 15, No. 3, June 2006. 255-270. Diunduh 5 Maret 2009.

Sanchez, L.E., \& Le, L.T. ( 2001). Suicide in Mood Disorders.Depression and Anxiety. 14: 177-182, 2001. WileyLiss, Inc. Diunduh 7 September 2009

Santoso, A.G., \&Royanto, R.M.L. (2009).Teknik Penulisan Laporan Penelitian Kualitatif. Jakarta: LPSP3 Fakultas Psikologi Universitas Indonesia

Santrock, W.J. (2008). Life-Span Development. 8 Edition. New York : Mc Graw Hill

Shaughnessy, J. J., \& Zechmeister, E.B. (1994). Research Methods in Psychology. New York: McGraw Hill Inc

Spirito, A., Boergers, J., \&Donaldson, D. (2000). Adolescent Suicide Attempters: Post attempt Course and Implications for Treatment. Journal Clinical Psychology and Psychotherapy, 7 161-173.Diunduh 5 Maret 2009

Spirito, A., Overholser, J., Ashworth, S., Morgan, J., \& Benedict-Drew, R. (1988). Evaluation of aSuicide Awareness Ccurriculum for High School Students. Journal of the American Academy of Child and Adolescent Psychiatry, 27,705-711. Diunduh 23 Februari 2010 